\title{
Durum Buğday Genotiplerinin (Triticum durum L.) Yüksek Sıcaklık Şartlarında Verim ve Bazı Kalite Özellikleri Yönünden Değerlendirilmesi
}

\author{
Hasan Kılıç \\ Bingöl Üniversitesi, Ziraat Fakültesi, Bingöl, Turkey \\ kilichasan@yahoo.com 1 D \\ Makale gönderme tarihi: 17.04.2020, Makale kabul tarihi: 30.06 .2020
}

\begin{abstract}
$\ddot{\mathbf{O} z}$
Güneydoğu Anadolu Bölgesi 1. ve 2. alt bölgeleri sulu yağışa dayalı şartlarında 2006/2007 yetiştirme döneminde yürütülen bu çalışmada; 25 durum buğday genotipinin tane verimi (TV) ile birlikte performans oranı (PERO) başaklanma süresi (BS) bin dane ağırlığı (BTA), hektolitre ağıllığı (HL), protein oranı (PO), mini SDS sedimentasyon testi (mSDS) ve tane rengi (b) gibi kalite özellikleri incelenmiştir. Tane verimi bakımından en yüksek değerler Diyarbakır sulu $\left(695 \mathrm{~kg} \mathrm{da}^{-1}\right)$ ve kuru $\left(638 \mathrm{~kg} \mathrm{da}^{-1}\right)$ şartlarından alınırken, en düşük verim de $\left(301 \mathrm{~kg} \mathrm{da}^{-1}\right)$ dane doldurma döneminde yüksek sıcaklığın hüküm sürdüğ̈̈ $\left(>35^{\circ} \mathrm{C}\right)$ Mardin-Göllü lokasyonundan alınmıştır. Çevre ve özellikler arası ilişkileri belirlemeye esas biplot analizinde, Göllü lokasyonu PO, mSDS ve b değeri bakımından öne çıkarken, Diyarbakır kuru ve sulu lokasyonları ise TV, BTA, HL, BS ve BB bakımından öne çıkmıştır. Genotip stabiliteleri bakımından G16 ve G7 yüksek verim seviyesine sahip spesifik bölgelere uygun genotipler olarak tanımlanırken G14 ise genel adaptasyon kabiliyeti en uygun genotip olarak belirlenmiştir.
\end{abstract}

Anahtar Kelimeler: Biplot, durum buğdayı, kalite, stres faktörleri, yüksek sıcaklık

\section{Evaluation of Durum Wheat (Triticum durum L.) Genotypes Based on Yield and Some Quality Traits in High Temperature Conditions}

\begin{abstract}
In this study, grain yield, relative performance, days to heading, plant height, thousand grain weight, hectoliter weight, protein content, mini SDS sedimentation test, grain color quality trait of 25 different durum wheat (Triticum durum L.) genotypes were investigated in supplemented irrigation, dry conditions in Diyarbakır province and rainy conditions in Mardin-Göllü location in 2006/2007 season. While the highest value in terms of grain yield obtained from Diyarbakır region in irrigation $\left(695 \mathrm{~kg} \mathrm{da}^{-1}\right)$ and dry $\left(638 \mathrm{~kg} \mathrm{da}^{-1}\right)$ conditions, the lowest value $\left(301 \mathrm{~kg} \mathrm{da}^{-1}\right)$ is from Göllü region where high temperatures prevail. In the biplot analysis that is for determining environment and genotype properties relations, while Göllü region came to the fore in terms of protein content, mini SDS and grain color values; Diyarbakır irrigation and dry regions came to the fore in terms of grain yield, thousand grain weight, hectoliter weight, days to heading and plant height. In terms of genotype stability, while G16 and G17 are defined as the best genotypes befitting into the high yielding regions, G14 is defined as the genotype with the best overall adaptation capability.
\end{abstract}

Key Words: Biplot, durum wheat, quality, stress factors, high temperatures

\section{GİRIŞ}

Beslenme amaçlı dünya enerji ihtiyacının \%60'1 buğday, misır ve çeltik türlerinin meydana getirdiği tahıl mahsullerinden (FAO, 2011), tüketilen tahıl kökenli proteinin de \%40'1 buğdaydan temin edilmektedir (Anonim, 2011; Elgün, 2017). Durum buğdayları dünya pazarlarında yüksek fiyatla alıcı bulan ürünler arasında yer almaktadır. Yaklaşık 735 mil ton olan dünya buğday üretimi içerisinde durum buğdaylarının payı 38.1 mil ha ile $\% 5.2$ civarındadır (TMO, 2019). Az sayıda ülkede yetiştirilebilmesi durum buğdaylarının ekonomik önemlerini artırmaktadır. Türkiye, Kanada ve İtalya'dan sonra 3.6 mil ton üretim ile 3. sirada yer almaktadır. Güneydoğu Anadolu Bölge'si 1.237 mil ton durum buğday üretimi ile ülke üretiminin \%36'lık kısmını oluşturmaktadır. Hammaddesini durum buğdaylarının oluşturduğu makarna üretimi bakımında ise Türkiye 1.667 mil. ton. ile ABD ve İtalya'nın ardından üçüncü sırada yer alıp, yıllık kişi başı tüketimi ise $7.3 \mathrm{~kg}$ 'dır (MÜSAD, 2019). Ayrıca Türkiye 1.230 mil ton bulgur üretimi ile de dünyanın 
en büyük bulgur üreticisi konumunda olup yıllık kişi baş1 tüketimi de 12 kg'dır (TMO, 2019). Durum buğdaylarının yetiştirilmesi açısından uygun iklime sahip olan ve aynı zamanda buğdayın gen merkezi olarak kabul edilen Güneydoğu Anadolu Bölgesi kaliteli durum buğday üretimi açısından dünyanın sayılı yerlerinden birisi olmakla kalmayıp hatta en uygun yeri de denilebilir. Durum buğday ve kalitesi ile alakalı ülkemizde yapılan çalışmalarda arzu edilen yüksek kalitede ürün elde edilmektedir (Atlı ve ark., 1993; Kılıç, 2003; Kılıç ve ark., 2005; Atlı, 2007; Coşkun ve ark., 2010; Kendal ve ark., 2012; Çetinkaya ve ark., 2013; Kızılgeçi ve ark., 2019). Atlı (2007), durum kalite özellikleri bakımından Orta, Ege, Trakya, Akdeniz ve Güneydoğu Anadolu bölgelerini mukayese ettiği çalışmasında Güneydoğu'yu fiziki özellikler, protein ve camsılık oranı bakımından en uygun bölge olarak tanımlamıştır. Dane doldurma devresindeki yüksek sıcaklıklar ülkemizde olduğu gibi dünyanın birçok yerinde de buğday verimini düşüren veya sınırlayan önemli bir stres faktörü olarak görülmektedir (McDonald ve ark., 1983; Rawson, 1986; Wardlaw ve ark., 1989a; Wardlaw ve Wrigley, 1994). Yüksek sıcaklığa bağlı tane veriminin azalması dane ebadındaki küçülmenin sonucu olarak ortaya çıkmaktadır (Wardlaw ve ark., 1989b). Başaklanma sonrası dane dolum devresinde $15{ }^{\circ} \mathrm{C}$ civarındaki sıcaklık en yüksek bin dane ağırlığını temin etme açısından optimum sıcaklık derecesi olarak kabul edilmektedir (Chowdhury ve Wardlaw, 1978). Gerek kontrollü (Wardlaw ve ark., 1989) ve gerekse tarla şartlarında (Wiegand ve Cuellar 1981) dane doldurma devresindeki her $1{ }^{\circ} \mathrm{C}$ lik sıcaklık artışı dane ebadında yaklaşık \%3-5 oranında bir azalışa sebep olmaktadır. Yüksek sicaklığa tolerantlık bakımından genotipik farklılığın bulunması bitki 1slahçılarını bu yönde çeşit geliştirmede cesaretlendirmektedir. Wardlaw ve ark., (1989b) 66 buğday çeşidi ile dane doldurma dönemini yüksek sicaklığa $\left(30 / 25{ }^{\circ} \mathrm{C}\right.$ gündüz/gece) maruz birakarak yürüttüğü çalışmasında tek dane ağırlığının serin şartlara göre en hassas genotiplerde \%60, en dayanıklı genotiplerde ise $\% 30$ azaldığını belirlemiştir. Kılıç ve ark., (1999) 7 durum buğday çeşidi ile sıcak stresi şartlarında yürüttükleri bir çalışmada sıcaklık stresine verilen tepki bakımından çeşitler arasında farkların olduğunu en uygun çeşidin Diyarbakır-81 olduğunu bildirmişlerdir. Sial ve ark., (2005) 12 buğday çeşidi ile sıcaklık stresi şartlarında yaptıkları çalışmada bayrak yaprağın yeşil kalma süresinin genetik olarak farklılık gösterdiğini ve genotipler arasında belirgin farkl11ıkların olduğunu bildirmişlerdir. Tekdal ve Yıldırım (2017) bölgede yaygın durum buğday çeşitleri ile yürüttükleri bir çalışmada sıcaklık stresine en tolerant çeşitlerin Diyarbakır-81 ve Fırat-93 olduğunu bildirmişlerdir. Dane doldurma devresindeki yüksek sıcaklıklar aynı zamanda dane doldurma süresinin azalmasına da sebep olduğu yapılan çalışmalarla belirlenmiştir. Nitekim, her $1{ }^{\circ} \mathrm{C}$ lik sıcaklık artışı dane doldurma süresini yaklaşık olarak 3 gün kısaltırken (Wiegand ve Cuellar, 1981), dane doldurma süresinin $20-30{ }^{\circ} \mathrm{C}$ sıcaklıklar arasında daha satabil bir seyir takip ettiği bildirilmiştir (Zahedi ve Jenner, 2003). Bitkilerde kuraklığın olumsuz etkileri ilave sulama ile en aza indirilebilirken, yüksek sıcaklığın etkilerine müdahale o kadar kolay olmamaktadır. Öte yandan kurak ve yüksek sıcaklığın birlikte etkisi yalnız başlarına yaptığ 1 etkiden daha fazla, başka bir ifade ile kuraklığın etkisi yüksek sicaklıkta $\left(35 / 30{ }^{\circ} \mathrm{C}\right.$ gündüz/gece) daha şiddetli olmaktadır (Shah ve Paulsen, 2003). Fotosentetik aktiviteyi incelemeye esas sapa kalkma ve dane doldurma dönemi sonlarında 3 gün boyunca12'şer saat $30{ }^{\circ} \mathrm{C}$ civarı, 3 'er saat de gün ortasında $38{ }^{\circ} \mathrm{C}$ yüksek sicaklık şokuna maruz birakılan bitkilerde yüksek sıcaklık şokunda gerek fotosentez oranı ve gerekse dane gelişiminin yavaşladığı, çeşitlere ve gelişme devrelerine göre değişmekle birlikte yaprak fotosentez oranının da \%40-70 arasında azaldığ bildirilmiştir (Schapendonk ve ark., 2007). Güneydoğu Anadolu Bölgesinde tane doldurma döneminde zaman zaman seyreden aşırı sıcaklıklar $\left(>35{ }^{\circ} \mathrm{C}\right)$ halk arasında şevib olarak isimlendirilen dane buruşukluğu ile tane veriminde azalmalara sebep olmaktadır. Söz konusu stres faktörünün geçmişe nazaran önemli oranda şiddetlendiği uzun y1llar verileri üzerinden (1950-2017) iklim değişimini esas alan bir çalışmadan da anlaşılmaktadır. Yaklaşık 60 yıllık bir periyot içerisinde Mardin bölgesinde y1llık yağışta \%45 azalış, yıllık sıcaklıkta ise $\% 1.5{ }^{\circ} \mathrm{C}$ gibi önemli bir artış tespit edilmiştir (Bayer ve Altın, 2019). Kılıç (2003), başaklanma-erme süresi (dane doldurma süresi) bakımından 12 durum buğday çeşidi ile 1 . ve 2. alt bölgelerde yürüttüğü bir çalışmada iki yıllık ortalamalara göre en uzun erme süresinin Diyarbakır lokasyonunda (43.9 gün), en kısa erme süresinin ise yüksek sıcaklığın hâkim olduğu 1. alt bölgede yer 
alan Ceylanpınar lokasyonundan (35.4 gün) elde dildiğini bildirmiştir. $\mathrm{Bu}$ açıdan bölgede yüksek s1caklık en az kuraklık kadar potansiyel bir risk veya cansız faktör olarak görülmelidir. Bu sebeple yüksek sicaklığa tolerant genotiplerin belirlenerek üretime kazandırılması verimi muhafaza etmede önemli bir strateji olarak değerlendirilebilir. Bu çalışmada 25 genotiple 2. alt bölgede yer alan ve kısmen optimal şartlara sahip Diyarbakır sulu-kuru ile yeterli yağışın alındığı ancak yüksek sıcakların hüküm sürdüğü ve 1 alt bölgede yer alan Mardin-Göllü olmak üzere toplam 3 lokasyonda tane verimi ile birlikte bazı kalite özelliklerinde meydana gelen değişimler incelenmeye çalışılmıştır.

\section{MATERYAL VE METOT Materyal}

Araştırma 2006/2007 ekim sezonunda 1.alt bölgede yer alan Mardin-Göllü köyü ile Diyarbakır sulu ve yağışa dayalı şartlarında yürütülmüştür (Çizelge 1 ve Şekil 1).

\section{Deneme alanlarının toprak yapısı}

Alüvyal yapıya sahip olan Mardin il toprakları killi bünyeli, hafif alkalin reaksiyonlu, organik madde içerikleri çok az, fazla kireçli, hafif tuzlu, potasyum içerikleri çok yüksek özellikler taşıdığı belirlenmiştir (Anonim, 2008). Diyarbakır lokasyonundaki deneme yeri toprakları, genellikle kırmızı-kahverengi büyük toprak grubuna giren, killi bünyede düz veya düze yakın meyilde, erozyonu çok az olan derin veya orta derin zonal topraklardir. Yapılan analizler sonucunda deneme yeri topraklarının ağır bünyeli (\%74) , hafif alkali (7.61), kireçli $(\% 0.83)$ ve organik madde yönünden fakir (\%1.3), fosforca orta, potasyumca zengin durumda olduğu tespit edilmiştir (Kılıç ve Türk, 2016).

\section{Deneme lokasyonlarının iklim özellikleri}

Son zamanlarda tüm dünyada olduğu gibi ülkemizde bilhassa Güneydoğu Anadolu Bölgesi'nde sıcaklıkların belirgin bir şekilde artığ görülmektedir. Türkiye uzun yıllar ortalama sicaklıklara bakıldığında 1970-1978 yılları ortalamas1 $12.7^{\circ} \mathrm{C}$ iken, 1997-2006 yıllar1 aras1 periyotta $13.4^{\circ} \mathrm{C}, 2007-2016$ yetişme döneminde ise $13.9{ }^{\circ} \mathrm{C}$ ye çıktığ 1 bildirilmiştir, (MGM, 2020). Maksimum ortalama sicaklıklar bakımından 1970 2018 yılları arası değerlendirildiğinde pozitif lineer bir ilişki $(y=0,0411 \mathrm{x}+18,023)$ tespit edilmiştir. Buradan 1sınmanın gelecekte de artışla devam edeceği izlenimini vermekte olup, Şen ve ark (2017)

Çizelge 1. Denemelerin yürütüldüğü lokasyon özellikleri

\begin{tabular}{|llll|}
\hline Lokasyon & Konum & İrtifa & Yetiştirme şartları \\
\hline Diyarbakır sulu & $37^{\circ} 56,38 \mathrm{~N}, 40^{\circ} 15,10 \mathrm{E}$ & $601 \mathrm{~m}$ & İlave sulama \\
\hline Diyarbakır kuru & $37^{\circ} 56,38 \mathrm{~N}, 40^{\circ} 15,08 \mathrm{E}$ & $601 \mathrm{~m}$ & Yağışa dayalı \\
\hline Mardin-Göllü Kuru & $37^{\circ} 15,19 \mathrm{~N} ; 40^{\circ} 43,03 \mathrm{E}$ & $570 \mathrm{~m}$ & Yağışa dayalı \\
\hline
\end{tabular}

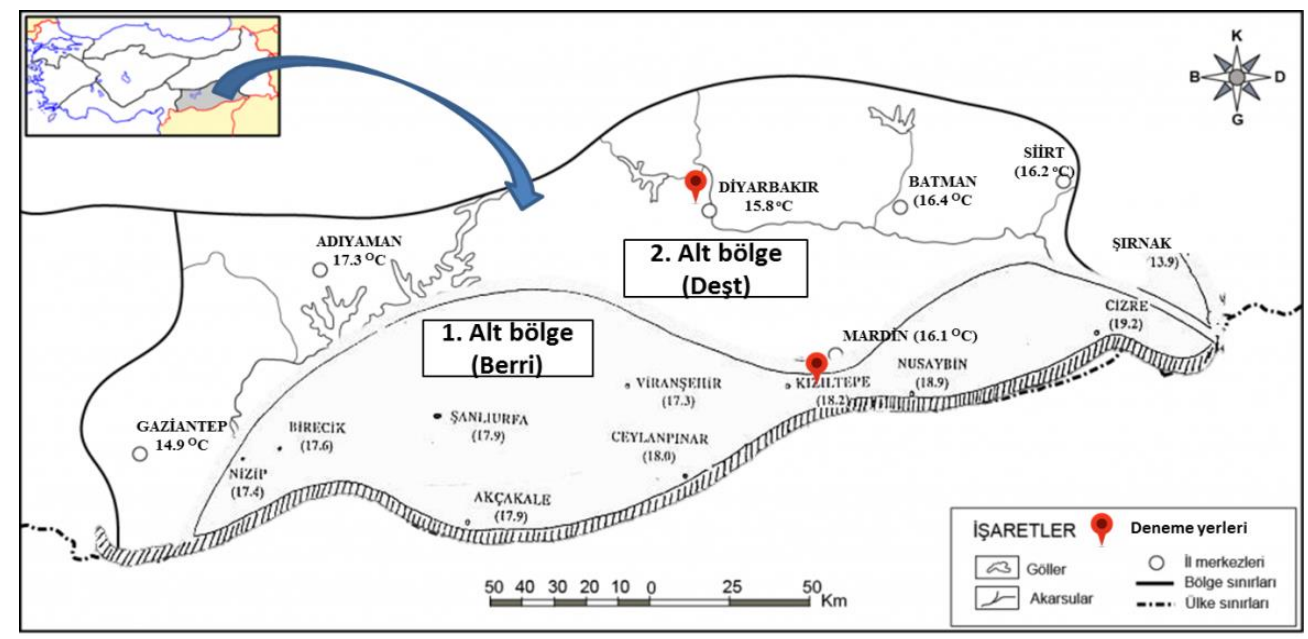

Şekil 1. İki alt bölgeden oluşan Güneydoğu Anadolu bölgesine ait ortalama sıcaklıklar 
tarafindan 2010-2100 periyoduna ilişkin yapılan bir değerlendirmede yıllık sıcaklık artışının Doğu ve Güneydoğu bölgelerinde diğer bölgelere (sahil) nazaran daha fazla olacağının tahmin edildiği belirtilmiştir. Söz konusu durumlar, yüksek sıcaklığa tolerant çeşit geliştirmenin önemini teyit etmektedir.

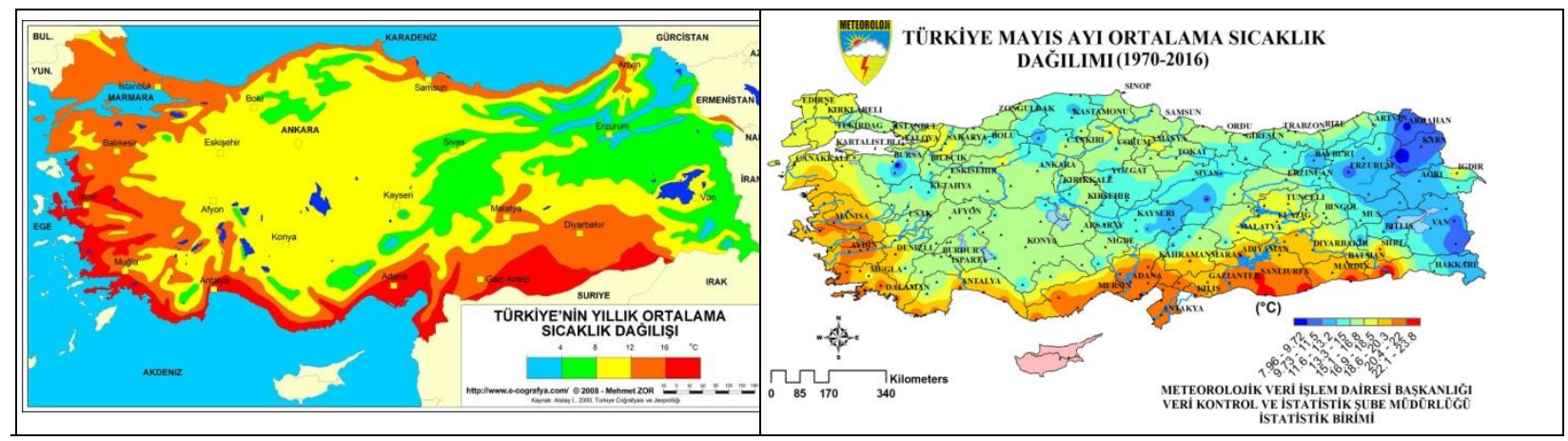

Şekil 2. Türkiye ortalama sıcaklık dağılışı (URL-1)

İklim ve rakım yönünden iki alt agroekolojik bölgeden oluşan (Şekil 1) Güneydoğu Anadolu bölgesi, sahip olduğu yüksek sıcaklık ortalaması bakımından ülkemizin sayılı yerlerinden birisidir. Denmenin yürütüldüğü Diyarbakır lokasyonu, 2. alt bölgede yer almakta olup daha düşük sıcaklık ve yüksek yağış ortalamasına sahip iken, 1. alt bölgede yer alan Göllü lokasyonu ise daha yüksek sıcaklık ve daha düşük yağış ortalamasına sahiptir (Şekil 1)
Şekil 3. Türkiye Mayıs ayı ortalamam sıcaklık dağılışı (URL-1)

Denemelerin yürütüldüğü 2006-2007 yetiştirme sezonuna ait yıllık yağış miktarı uzun yıllar ortalamasının üzerinde kaydedilmiştir (Şekil 4). Buğday yetiştiriciliği açısından önemli olan gün içindeki en yüksek sıcaklık değerleridir. Buğday tane doldurma döneminde maksimum sicaklık değeri 30-32 ${ }^{\circ} \mathrm{C}$ kabul edildiğinden bu değerlerin üzerindeki sicaklıklar fotosentez hizını tedrici olarak düşürmektedir. Şekil 5 ve Şekil 6'da Mayıs-Haziran

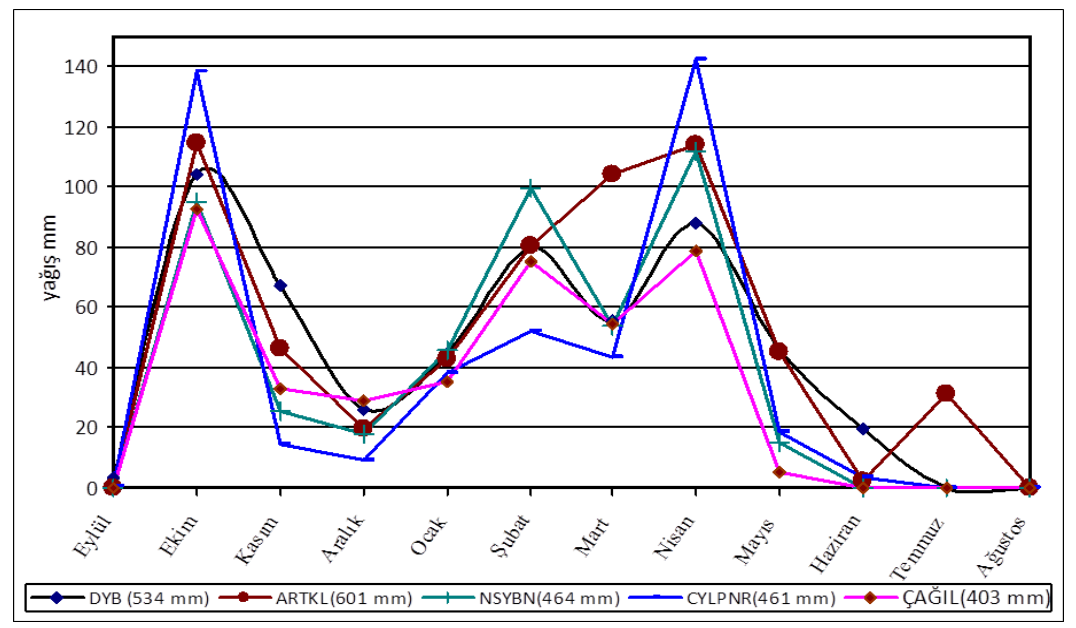

Şekil 4. Deneme lokasyonları ve lokasyonlara yakın merkezlere ait 2006-2007 yılı yağış verileri

aylarına ait günlük en yüksek sıcaklık değerleri verilmiştir. Diyarbakır loksayonunda buğdaylar bu devrede henüz başaklanmamışken Göllü lokasyonunda 25 Nisan'da başlayan dane doldurma, yaklaşık 25 Mayıs'a kadar devam etmiştir. Bu devrede Mayıs ilk haftasında gün içi $37{ }^{\circ} \mathrm{C}$ 'yi bulan yüksek sıcaklık değerleri kısa bir süreliğine de olsa fotosentez verimi ve oranında önemli düşmelere sebebiyet verdiği yapılan çok sayıda çalışma ile de belirlenmiştir. Göllü lokasyonunda dane 
doldurma devresinin 2 ve 3 . haftalarında yüksek sicaklık sınır değerlerde $\left(28-30{ }^{\circ} \mathrm{C}\right)$ seyrederken 3 . haftada tekrar artış göstererek $40^{\circ} \mathrm{C}$ 'lere çıktığından bitkilerde şok 1s etkisi oluşturmak suretiyle fotosentezin sonlanmasına sebebiyet vermiştir (Şekil 8.)

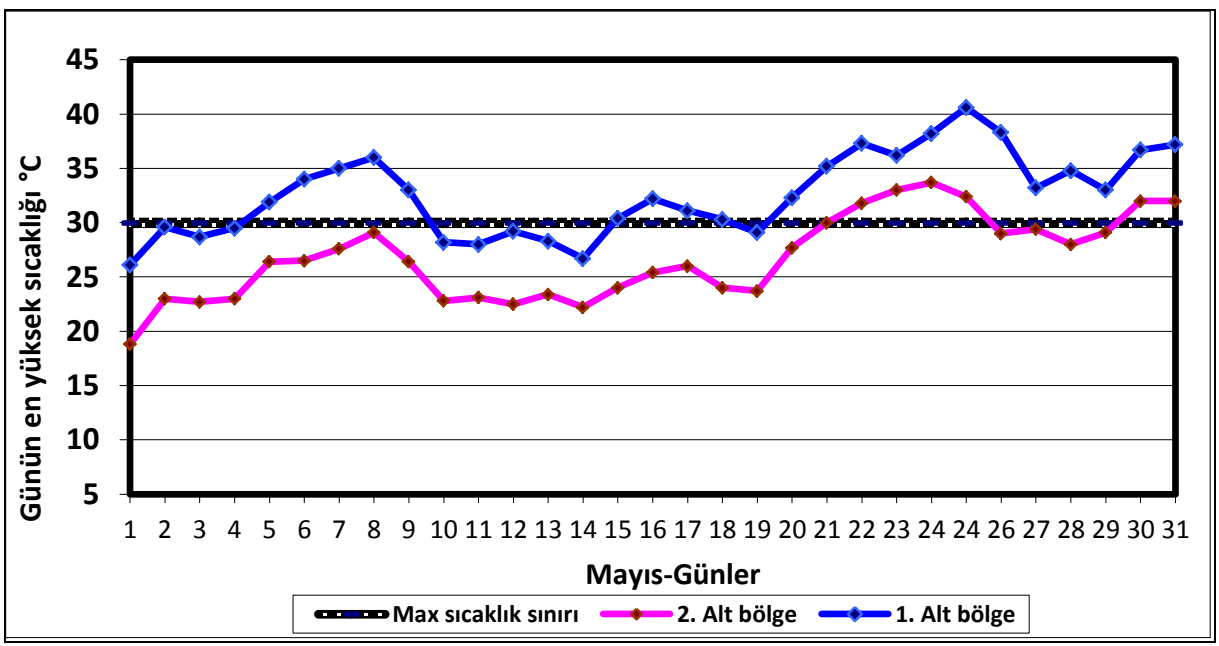

Şekil 5. Güneydoğu Anadolu Bölgesi 1. ve 2. alt bölgeler 2007 Mayıs ayı günlük en yüksek sıcaklık değerleri

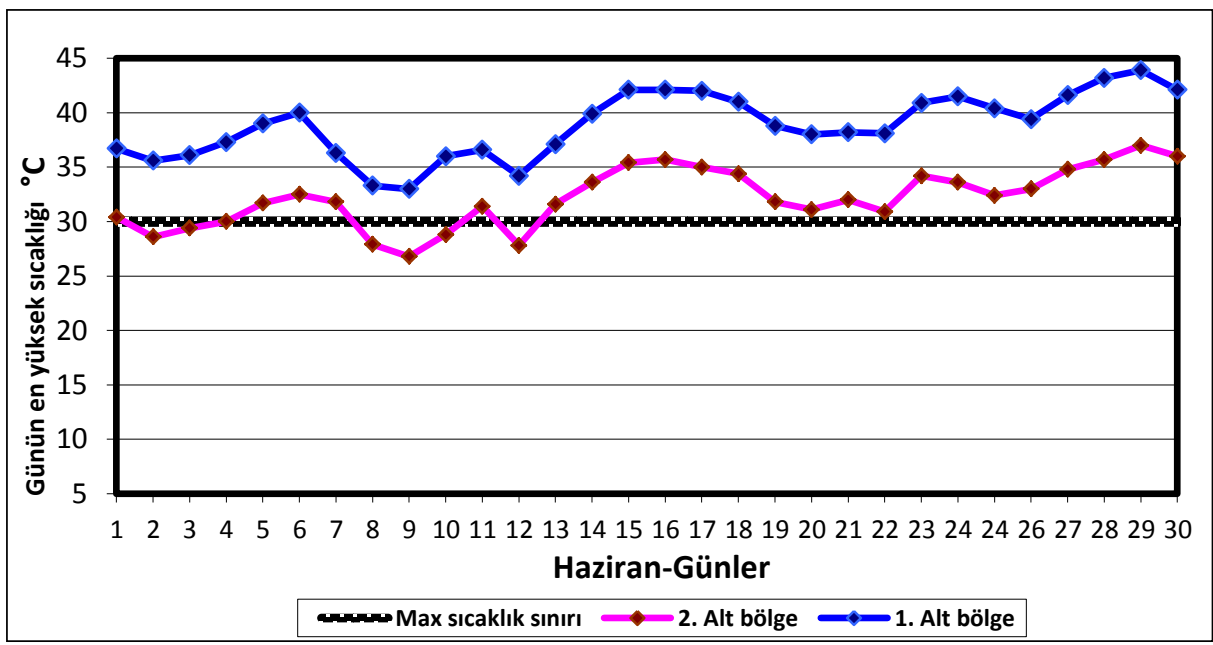

Şekil 6. Güneydoğu Anadolu Bölgesi 1. ve 2. alt bölgeler 2007 Haziran ayı günlük en yüksek sıcaklık değerleri 


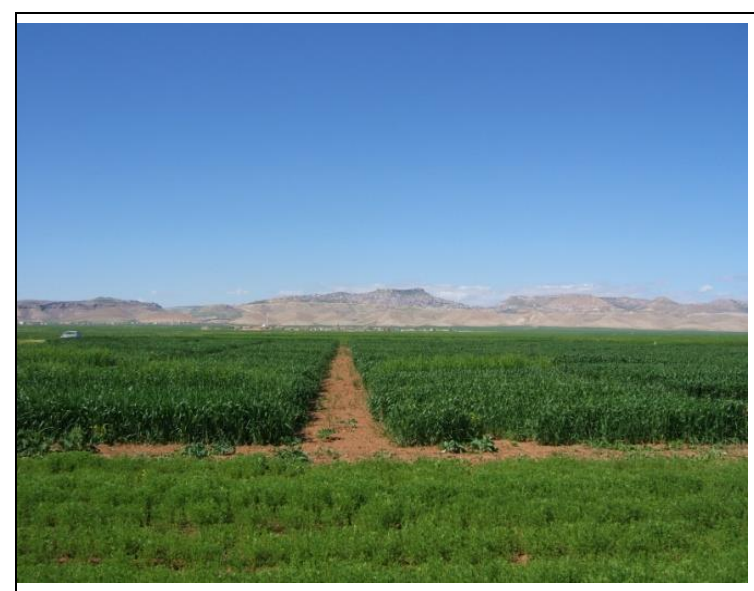

Şekil 7. Başaklanma başlangıcı Mardin-Göllü lokasyonundan bir görüntü

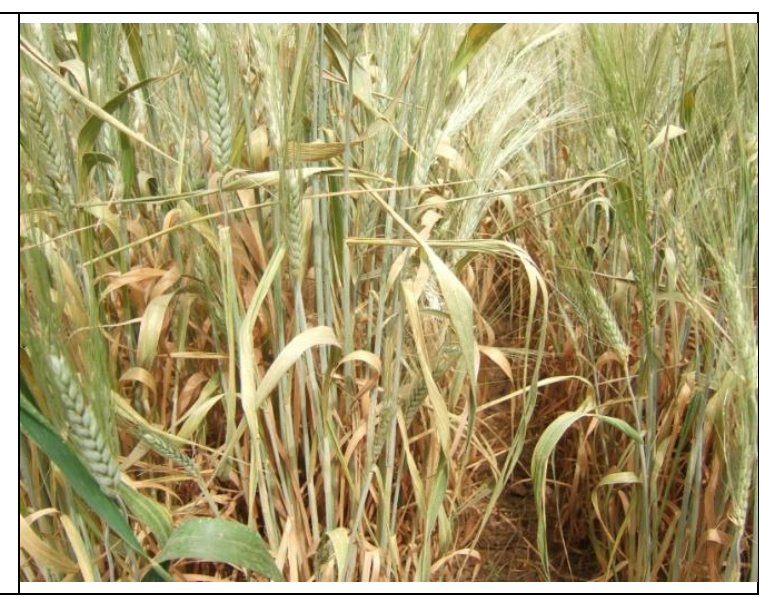

Şekil 8. Mayıs ayında yaşanan şok sıcaklıkların $\left(>35^{\circ} \mathrm{C}\right)$ Mardin-Göllü lokasyonunda bitkilerde sebep olduğu kavrulma

\section{Denemelerde Kullanılan Genotipler}

Denemede materyal olarak, GAP Uluslararas1 Tarımsal Araştırma ve Eğitim merkezince tescil ettirilen Frrat-93, Aydın-93 ve Sarıçanak-98; Batı Akdeniz Tarımsal Araştırma Enstitüsüne ait

Fuatbey-2000 ile Tasaco firmasina ait Svevo durum buğday çeşitleri ile ulusal program, ICARDA ve CIMMYT den temin edilen 20 ileri hat kullanılmıştır (Çizelge 2).

Çizelge 2. Denemede kullanılan çeşit ve hatlara ait pedigriler

\begin{tabular}{|c|c|c|c|c|c|}
\hline G NO: & Pedigri & Menşei & G No: & Pedigri & Menşei \\
\hline G1 & SOOTY-9/RASCON-37 & GAPUTAEM & G14 & BOOMER_18/LOTUS_4 & CIMMYT \\
\hline G2 & $\begin{array}{l}\text { Misri/Mexi//Snipe"s"\#Mudhen"s"=Men"s' } \\
\text { '/3/85-16 }\end{array}$ & GAPUTAEM & G15 & FUATBEY-2000 & GAPUTAEM \\
\hline G3 & Ru's"/Minaret Durum & GAPUTAEM & G16 & HALO_2/CHAIKA_3 & CIMMYT \\
\hline G4 & KUCUK & CIMMYT & G17 & $\begin{array}{l}\text { SHAW//FG/CR/3/YAV/4/CNDO/YAV//PAL/5/C } \\
\text { HAHBA88/DERAA }\end{array}$ & ETAE \\
\hline G5 & AYDIN-93 & GAPUTAEM & G18 & BOOMER_33/FOCHA_1//MEMO_1/YAV79 & CIMMYT \\
\hline G6 & YAVAROS 79 & CIMMYT & G19 & GREEN_14//YAV_10/AUK & CIMMYT \\
\hline G7 & $\mathrm{Stj} 3 / / \mathrm{bcr} / \mathrm{lks} 4$ & CIMMYT & G20 & SARIÇANAK-98 & GAPUTAEM \\
\hline G8 & TOTUS/CARGO//ALTAR 84/AOS & CIMMYT & G21 & RUFF/FG//TURK-1/3/GENIL-3 & ICARDA \\
\hline G9 & $\begin{array}{l}\text { SN TURK MI83-84 375/NIGRIS- } \\
\text { 5//TANTLO-1 }\end{array}$ & GAPUTAEM & G22 & RUFF/FG//TURK-1/3/BRACHOUA & ICARDA \\
\hline G10 & FIRAT-93 & GAPUTAEM & G23 & $\begin{array}{l}\text { AAZ'S'/CREX'S'/3/SRN//HUI'S'/SOMO'S'/4/A } \\
\text { OS'S'/KKV5//CHEN'S'DRN'S' }\end{array}$ & CIMMYT \\
\hline G11 & PI290493//HUI/YAV79 & EAE & G24 & WIZZA_23/CONA & CIMMYT \\
\hline G12 & DF28.82.84/GAN//RASCON-19 & CIMMYT & G25 & SVEVO & TASACO \\
\hline G13 & Ru's"'/ 85-16 & GAPUTAEM & & & \\
\hline
\end{tabular}

GAPUTAEM: GAP Uluslararası tarımsal araştırma ve eğitim merkezi, CIMMYT: International maize and wheat improvement center, ICARDA: International center for agricultural research in the dry areas, DATE: Doğu akdeniz Araş. Enst.; ETAE Ege tarımsal araştırma enstitüsü

\section{Metot}

Denemeler, Tesadüf Blokları Deneme deseninde 4 tekerrürlü olarak kurulmuştur. Deneme parselleri 1.2 x $6=7.2 \mathrm{~m}^{2}$ olmak üzere $\mathrm{m}^{2}$ ye 450 canlı tohum düşecek şekilde ekim yapılmıştır. Diyarbakır kuru için dekara toplam $6 \mathrm{~kg}$ saf $\mathrm{P}_{2} \mathrm{O}_{5}$ ve $12 \mathrm{~kg}$ saf $\mathrm{N}$, Diyarbakır sulu için $7.5 \mathrm{~kg}$ saf $\mathrm{P}_{2} \mathrm{O}_{5}$ ve $15 \mathrm{~kg}$ saf N, Göllü lokasyonunda ise uzun yıllar düşük yağıŞ rejimi düşünülerek $5 \mathrm{~kg}$ saf $\mathrm{P}_{2} \mathrm{O}_{5}$ ve $10 \mathrm{~kg}$ saf $\mathrm{N}$ gelecek şekilde gübreleme yapılmış olup, $\mathrm{P}_{2} \mathrm{O}_{5}$ 'in 
tamamı ile N'nın yarıs1 ekimle kalan N'nın yarıs1 da 3. boğumun görüldüğü sapa kalkma döneminde verilmiştir. DYB-S lokasyonu gebecik devresinde salma sulama yöntemi ile yaklaşık $30 \mathrm{~mm}$ 'lik su verilmiştir. Tane verimi, başaklanma süresi ve bitki boyu Anonim (2001) göre, hektolitre ağırlığ1 ve bin dane ağırlığ1 Williams ve ark., (1988)'e göre, mini SDS sedimentasyon değeri ve protein oranı Tanede protein iceriği ise kalibre edilen NIR.6500 (Near Infra Red Spestroscopy) cihazı ile tayin edilmiştir. İrmikte renk analizi (b değeri) Minolta-3220d marka masa tipi spektrofotometre cihazıyla yapılmıştır. parametrelere ait değerlerin varyans analizleri JMP-5 SAS (2002) istatistik paket programı kullanılarak yapılmıştır. Önemli bulunan faktör ortalamaları arasındaki fark Tukey (\%5) testine göre gruplandırılmıştır. Ancak tane verimi dışında diğer özelliklerde tekerrürler üzerinden analiz edilmediğinden genotipler gruplandırılamamıştır. Tane verimi için Asana ve Williams (1965); Elbashir ve ark., (2017) tarafindan tanımlanan performans oranı (PERO) aşağıda belirtilen formüle göre hesaplanmıştır.

Performans Orani $(P O)=\frac{\mathrm{SP}}{O P} \times 100$

Burada, SP yüksek sicaklığın etkili olduğu lokasyondaki genotipin tane verimi, OP ise optimum şartların etkili olduğu lokasyondaki tane verimini temsil etmektedir. PO'yu belirlemeye esas normal kabul edilen Diyarbakır lokasyonu ile sıcaklık stresinin yaşandığı Göllü lokasyonu arasında agroeklojik farkl11ıklar olmakla birlikte verimi düşüren temel stres faktörünün ağırlıklı olarak yüksek sıcaklık olduğu Şekil 4, Şekil 5 ve Şekil 6'dan da anlaşılabilmektedir. Çalışmada özellikler arası ilişkileri görsel olarak inceleme ve değerlendirmek amaciyla genotip verileri ile oluşturulan GGE Biplot analizleri, Yan (2001) ile Yan ve Kang (2003)'ın belirttiği yöntemler esas alınarak gerçekleştirilmiş, grafiklerdeki önemlilik dereceleri ise vektör grafiklerindeki vektörler arası açılar dikkate alınarak belirlenmiştir. (Yan, 2002; Yan ve Kang 2003; İlker ve ark., 2009; Kendal ve Sayar, 2016; Aktaş ve ark., 2017). Çalışmada GGE Biplot analiz grafikleri Genstat 14th istatistik paket programı kullanılarak yapılmıştır.

Çizelge 3. Denemelerin yürütüldüğü Diyarbakır ve Göllü lokasyonlarına ait bazı gözlem tarihleri.

\begin{tabular}{llll}
\hline Gözlemler & \multicolumn{2}{c}{ 2. Alt Bölge } & 1. Alt bölge \\
\cline { 2 - 4 } & Diyarbakır Kuru & Diyarbakır sulu & Mardin-Göllü \\
\hline Ekim Tarihi & 25 Kasım 2006 & 25 Kasım 2006 & 21 Kasım 2006 \\
\hline Çıkış Tarihi & 12 Şubat 2007 & 12 Şubat 2007 & 15 Ocak 2007 \\
\hline Ort. Başaklanma Tarihi & 9-14 Mayıs 2007 & 10-16 Mayıs 2007 & 25 Nisan-03 Mayıs 2007 \\
\hline Ortalama Erme süresi & 15-17 Haziran & 16-18 Haziran & 24-26 Mayıs 2007 \\
\hline Hasat tarihi & 28 Haziran 2007 & 28 Haziran 2007 & 30 Mayıs 2007 \\
\hline
\end{tabular}

\section{SONUÇLAR VE TARTIŞMA \\ Başaklanma süresi}

Başaklanma süresi (BS) bakımından lokasyonlar değerlendirildiğinde, DYB-S ile DYB-K lokasyonları arasında farkın olmadığı görülmektedir. Yaklaşık 534 mm lik yağışın alındığı Diyarbakır'da ilave sulamanın buğday verimine önemli bir etkisinin olmadığ $\breve{1}_{1}$ anlaşılmaktadır. Yaklaşık 400$460 \mathrm{~mm}$ yağışın alındığı Göllü lokasyonunda ise BS'nin daha kısa sürede gerçekleştiği (112.3 gün) görülmüsşür. Başaklanma yüksek derecede kalıtsal bir özellik olmakla birlikte (Fırat, 1978; Kanbertay, 1987) yapılan çalışmalar çevre etkisinin de göz ardı edilemeyeceğini ortaya çıkarmıştır (Sakin ve ark., 2004; Bilgin ve Korkut, 2005). Buğdayda 15-20 ${ }^{\circ} \mathrm{C}$ 'nin üzerindeki $1{ }^{\circ} \mathrm{C}$ 'lik artışların tane dolum dönemini 2.8 günlük kısalmaya yol açtığı tahmin edilmektedir (Yiğit ve Erekul 2018). Dane doldurma süresini uzatmasi ve danede daha fazla asimilant madde birikimine firsat vermesi açısından (Sharma, 1994) yüksek sıcaklık, kuraklık ve kuru rüzgârlar vb stres şartlarının hâkim olduğu bölgelerde erkenci çeşit önemli avantajlar sağlayabilmektedir (Blum, 1988). 


\section{Bitki boyu}

Bitki boyu (BB) bakımından DYB-S ile DYB$\mathrm{K}$ lokasyonları arasında fark görülmezken, Göllü lokasyonunun nispeten daha kısa boylu olduğu $(100.5 \mathrm{~cm})$ görülmüştür. Her 3 lokasyonda yağışların yeter olması bitki boylarının birbirine yakın değerlerde olmasını sonuç vermiştir. BB genotip tarafından belirlenen bir özellik olmasına rağmen özellikle kuraklığın BB'nin kısalmasında önemli bir etken olduğu bilinen bir gerçektir. Mut ve ark., (2006); Sakin ve ark., (2015) BB'nin yăğış miktarının düşük olması ve ortalama sicaklığın yüksekliğine bağlı olarak azaldığını bildirmişlerdir.

\section{Bin tane ağırlı̆ğ}

Bin tane ağırlığı (BTA) bakımından, DYB-S $(37.6 \mathrm{~g})$ ve DYB-K (39.9 g) önemli bir fark görülmezken, Göllü lokasyonunda önemli oranda düşük bir ağırlık $(27.15 \mathrm{~g})$ tespit edilmiştir (Çizelge 4). BTA'da yeterli yağıșa rağmen Göllü lokasyonunda $27.15 \mathrm{~g}$ gibi düşük bir değerin elde edilmesi çevre şartlarının özellikle yükseksıcaklığın varlığı ile izah edilebilir. Dane doldurma süresinde meydana gelen $30-35{ }^{\circ} \mathrm{C}$ ve üzeri yüksek sıcaklıklar (Şekil 4, Şekil 5 ve Şekil 6) fotosentetik faaliyetlerin yavaşlaması ve daneye taşınan asimilantların azalması sonucu BTA'da önemli

Çizelge 4. Denemelerin yürütüldüğü lokasyonlara ait başaklanma süresi, bitki boyu ve bin tane ağırlığına ait ortalamalar

\begin{tabular}{|c|c|c|c|c|c|c|c|c|c|}
\hline \multirow[b]{2}{*}{ Genotip } & \multicolumn{3}{|c|}{ Başaklanma Süresi (gün) } & \multicolumn{3}{|c|}{ Bitki Boyu (cm) } & \multicolumn{3}{|c|}{ Bin Tane Ağırlı̆̆ı (g) } \\
\hline & DYB-S & DYB-K & GÖLLÜ & DYB-S & DYB-K & GÖLLÜ & DYB-S & DYB-K & GÖLLÜ \\
\hline 1 & 134 & 134 & 125 & 95 & 95 & 95 & 33,8 & 31,8 & 26,2 \\
\hline 2 & 134 & 134 & 125 & 105 & 105 & 90 & 38,0 & 37,4 & 24,5 \\
\hline 3 & 133 & 133 & 124 & 110 & 110 & 95 & 41,9 & 40,6 & 26,7 \\
\hline 4 & 132 & 132 & 122 & 105 & 105 & 105 & 30,8 & 33,2 & 26 \\
\hline Aydın-93 & 135 & 135 & 124 & 110 & 110 & 110 & 36,2 & 37,4 & 27,2 \\
\hline 6 & 130 & 130 & 120 & 100 & 100 & 95 & 38,0 & 37,4 & 27 \\
\hline 7 & 129 & 129 & 120 & 100 & 100 & 100 & 36,2 & 38,6 & 27 \\
\hline 8 & 130 & 130 & 122 & 100 & 100 & 105 & 35,2 & 33,0 & 23,7 \\
\hline 9 & 131 & 131 & 122 & 105 & 105 & 105 & 39,0 & 37,0 & 26,7 \\
\hline Firat-93 & 131 & 131 & 122 & 95 & 95 & 90 & 45,4 & 42,6 & 34,7 \\
\hline 11 & 136 & 136 & 125 & 115 & 115 & 100 & 39,6 & 35,4 & 24 \\
\hline 12 & 136 & 136 & 126 & 100 & 100 & 100 & 37,6 & 32,6 & 20,7 \\
\hline 13 & 132 & 132 & 125 & 105 & 105 & 105 & 40,8 & 36,6 & 23,2 \\
\hline 14 & 130 & 130 & 118 & 100 & 100 & 100 & 36,0 & 37,2 & 29,7 \\
\hline Fuatbey & 131 & 131 & 125 & 95 & 95 & 95 & 43,0 & 43,2 & 29,7 \\
\hline 16 & 131 & 131 & 123 & 105 & 105 & 103 & 38,2 & 41,6 & 28,7 \\
\hline 17 & 129 & 129 & 120 & 110 & 110 & 105 & 38,2 & 40,8 & 30,5 \\
\hline 18 & 130 & 130 & 122 & 105 & 105 & 105 & 31,8 & 33,0 & 23 \\
\hline 19 & 131 & 131 & 120 & 105 & 105 & 100 & 41,6 & 38,4 & 33 \\
\hline S.Çanak-98 & 130 & 130 & 120 & 95 & 95 & 95 & 39,4 & 36,4 & 27 \\
\hline 21 & 131 & 131 & 123 & 95 & 95 & 105 & 37,0 & 39,8 & 26,7 \\
\hline 22 & 130 & 130 & 122 & 100 & 100 & 100 & 41,8 & 31,6 & 29 \\
\hline 23 & 130 & 130 & 120 & 105 & 105 & 105 & 33,0 & 38,2 & 28 \\
\hline 24 & 131 & 131 & 122 & 105 & 105 & 100 & 34,8 & 35,0 & 27,2 \\
\hline Svevo & 130 & 130 & 121 & 105 & 105 & 105 & 33,6 & 35,8 & 28,7 \\
\hline Ortalama & 131.48 A & $131.48 \mathrm{~A}$ & 122.32 B & 103.6 A & 102.8AB & $100.5 \mathrm{~B}$ & 37.6A & 39.9A & 27.15B \\
\hline DK\% & & 5.9 & & & 4.2 & & & 6.9 & \\
\hline
\end{tabular}

*: Aynı harf grubuna giren değerler Tukey \%5 önem seviyesine göre farklı değildir. 
oranda düşme kaydedilmiştir. Tane dolum devresinde bayrak yapraktan taneye asimilant taşınım $130{ }^{\circ} \mathrm{C}$ 'nin üzerinde önemli oranda azalmaktadır (Farooq ve ark., 2011). Dane doldurma dönemindeki kuraklık ve yüksek sıcaklığın en belirgin olumsuz etkileri dane ebadında meydana gelen azalma (buruşuk dane) sonucu olarak BTA ile tane veriminin (Peterson ve ark., 1992) düşmesidir.

\section{Protein oranı}

Danede protein oran1 )PO) bakımından normal şartlara sahip DYB-S (\%11.66) ve SYB-K (\%11.69) arasında önemli bir fark görülmezken, Göllü lokasyonuna ait protein ortalamas1 \%15.2 ile yüksek bir değere sahip olmuştur. Dane doldurma devresinde Göllü lokasyonunda $30{ }^{\circ} \mathrm{C}$ ve üzeri seyreden sicaklıklar bitkilerin fotosentetik aktivitesini düşürmek suretiyle devrenin kisalmasina ve asimilantların bilhassa karbonhidratların dane içinde birikiminin azalmasına vesile olmuştur. Bunun sonucu, hacim olarak dane ebadı küçüldüğü gibi protein yoğunluğunun da artmasına sebep olmuştur. Dupont ve Albenbach, (2003) de dane dolum devrelerindeki sıcaklık artışının taneyi hacimsel olarak azaltarak, protein yoğunluğunun artmasına sebep olacağını bildirmiştir. Durum buğdaylarda $\mathrm{PO}$, irmik kalitesinin belirlenmesinde önemli bir yer tutmakla birlikte kullanım amacinı da etkileyen en önemli kalite özelliğidir (Kılıç ve ark, 2012). Güneydoğu Anadolu Bölge'sinde tanede PO'ya, seyreden yıllık yağış miktarı yanında, tane doldurma dönemindeki yüksek sıcaklıklar ve topraktaki azot miktarını önemli etkilerde bulunduğu söylenebilir (Kılıç, 2003). Bilindiği üzere PO üretici ve sanayici açısından fiyat belirlemede önemli bir kriter olup olarak kabul edilmektedir.

\section{SDS sedimentasyon testi}

Sedimentasyon testi (mSDS) testi bakımından diğer kalite özelliklerinde olduğu gibi DYB-S (6.12 $\left.\mathrm{mm}^{-1}\right)$ ve DYB-K $\left(6.22 \mathrm{~mm}^{-1}\right)$ arasinda önemli bir fark bulunmazken, Göllü lokasyonunda ise 10.02 $\mathrm{mm}$ ile en yükssek değere ulaşmıştır. Yüksek sıcaklık şartları, protein oranında olduğu gibi mSDS değerinin de yükselmesine vesile olmuştur. Benzer çalışmalarda Borghi ve ark. (1997) sıcak ve kurak şartlarda dalgalı verimle birlikte camsılık ve SDS sedimentasyon gibi kalite özellikleri açısından firsat olduğunu bildirirken, Castro ve ark. (2007), sicaklık stresinin protein kalitesi üzerinde önemli bir etkisinin olmadığını, Zhang ve ark. (2017);
Blumenthal ve ark. (1991); Graybosh ve ark. (1995); Dias ve ark. (2008); Zhang ve ark. (2017) gibi araştırıcılar da yüksek sıcaklık şartlarında SDS sedimentasyon değerinin düştüğünü bildirmişlerdir. Öte yandan aynı lokasyonlarad çalışma yürüten araştırıcılardan Kılıç ve Yağbasanlar (2003) 14 durum buğday çeşidi ile Diyarbakır, Ceylanpınar ve Akçakale de yürüttükleri bir çalışmada mSDS değeri bakımından her iki yılda da en yüksek değerlerin yüksek sıcaklık stres şartlarının hâkim olduğu Ceylanpınar $(29.6 \mathrm{~mm}$ ve $15.1 \mathrm{~mm}$ ) lokasyonunda, en düşük değerlerin de optimum şartların hakim olduğu Diyarbakır sulu (21.4 $\mathrm{mm}$ ve $12.0 \mathrm{~mm}$ ) lokasyonunda elde edildiğini; Karaduman ve Ercan (2011) Geçit bölgesi kuru şartlarında suluya göre daha yüksek SDS değerlerini bulduklarını, Tekdal (2015) durum buğday çeşitlerinin yüksek sıcaklığa karşı performanslarını belirlemek üzere yürüttüğü bir çalışmada dane doldurma dönemi yüksek sıcaklığa denk getirilen geç ekim zamanında normal ekim zamanına $(3.60 \mathrm{~mm})$ göre daha yüksek mSDS değeri $(5.06 \mathrm{~mm})$ elde ettiğini, benzer diğer bir çalışmada Barutçular ve ark (2016) da sıcaklık stresi altında zeleny testinin yükseldiğini bildirmişlerdir. SDS sedimantasyon değerinin yüksek olması gluten ağlarının kuvvetli olduğuna, makarnanın pişme sırasında organik maddelerinin suya geçme oranının düşük olacağına ve daha diri makarnaların elde edilebileceği anlamına gelmektedir (Aydoğan ve ark., 2012).

\section{Hektolitre ağırlığı}

Hektolitre ağırlığı (HL) bakımından yapılan varyans analizinde normal şartların hükmettiği DYB-S ve DYB- lokasyonlarında ( 81.53 ve $80.39 \mathrm{~kg} \mathrm{hl}^{-1}$ ) birbirine yakın değerler elde edilirken stres şartlarının yaşandığı Göllü lokasyondan $\left(72.59 \mathrm{~kg} \mathrm{~h}^{-1}\right)$ önemli bir düşüş tespit edilmiştir. Yüksek sıcaklık stresi altında hektolitre ağırlığının düşüş gösterdiğini birçok araştırıcı tarafindan da bildirilmiştir (Kılıç, 2003; Barutçular ve ark., 2016). Öte yandan Tekdal ve Yıldırım (2015) sicaklık stresi altında HL'de birinci yılda önemli bir değişme görülmezken, ikinci yılda önemli bir azalmanın olduğunu bildirmiştir

\section{Tanede sarı renk pigment içeriği}

Tanede sarı renk pigment içeriği (b) değeri yönünden yapılan varyans analizinde lokasyonlar arasında önemli bir fark çıkmıştır. DYB-S lokasyonunun analiz edilmediği çalışmada DYB-K (23.70) ile mukayese edildiğinde yüksek sicaklık 
Çizelge 5. Denemelerin yürütüldüğü lokasyonlara ait protein oranı, mSDS değeri ve hektolitre ağırlığına ait ortalamalar

\begin{tabular}{|c|c|c|c|c|c|c|c|c|c|}
\hline \multirow{3}{*}{$\begin{array}{l}\text { Genotip } \\
1 \\
\end{array}$} & \multicolumn{3}{|c|}{ Protein Oranı (\%) } & \multicolumn{3}{|c|}{$\operatorname{mSDS}\left(\mathrm{ml}^{-1}\right)$} & \multicolumn{3}{|c|}{ Hektolitre ağır. $\left(\mathrm{kg} \mathrm{hl}^{-1}\right)$} \\
\hline & \multirow{2}{*}{$\begin{array}{c}\text { DYB-S } \\
11.51\end{array}$} & \multirow{2}{*}{$\begin{array}{c}\text { DYB-K } \\
11.50\end{array}$} & \multirow{2}{*}{$\begin{array}{c}\text { GÖLL̈̈ } \\
15.2 \\
\end{array}$} & \multirow{2}{*}{$\frac{\overline{\text { DYB-S }}}{7.0}$} & \multicolumn{2}{|c|}{ 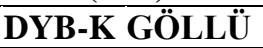 } & \multicolumn{3}{|c|}{ DYB-S DYB-K GÖLLÜ } \\
\hline & & & & & 7.00 & 10.5 & 79.7 & 75.8 & 71.4 \\
\hline 2 & 11.98 & 11.43 & 15.3 & 6.0 & 6.50 & 9.0 & 78.7 & 78.3 & 66.1 \\
\hline 3 & 12.21 & 12.62 & 15.9 & 8.0 & 8.50 & 12.5 & 82.4 & 80.4 & 71.6 \\
\hline 4 & 12.15 & 11.67 & 15.2 & 5.5 & 5.50 & 10.0 & 81.4 & 81.5 & 74.2 \\
\hline Aydin-93 & 12.33 & 12.28 & 15.1 & 5.0 & 5.50 & 10.0 & 84.1 & 80.9 & 75.3 \\
\hline 6 & 11.31 & 12.41 & 15.1 & 5.0 & 6.00 & 8.5 & 81.9 & 80.0 & 72.6 \\
\hline 7 & 10.64 & 10.79 & 14.9 & 5.5 & 7.00 & 11.0 & 82.6 & 81.3 & 73.9 \\
\hline 8 & 10.21 & 11.27 & 16.0 & 5.0 & 5.50 & 10.5 & 84.6 & 81.2 & 70.3 \\
\hline 9 & 12.57 & 11.14 & 15.3 & 5.5 & 8.00 & 11.5 & 81.8 & 79.3 & 70.5 \\
\hline Firat-93 & 11.6 & 11.27 & 15.2 & 5.0 & 4.50 & 9.0 & 83.3 & 81.5 & 75.4 \\
\hline 11 & 12.08 & 12.17 & 15.6 & 5.5 & 6.50 & 8.0 & 82.6 & 78.7 & 72.2 \\
\hline 12 & 10.84 & 11.94 & 15.6 & 5.0 & 3.50 & 5.0 & 80.6 & 77.5 & 63.8 \\
\hline 13 & 11.26 & 11.99 & 16.4 & 5.5 & 4.50 & 6.5 & 82.1 & 80.0 & 68.7 \\
\hline 14 & 11.61 & 11.57 & 13.9 & 7.0 & 6.00 & 11.0 & 83.2 & 81.7 & 75.2 \\
\hline Fuatbey & 10.85 & 11.43 & 14.9 & 7.5 & 6.00 & 12.0 & 81.6 & 80.4 & 73.6 \\
\hline 16 & 11.4 & 11.73 & 14.4 & 7.0 & 7.00 & 11.0 & 81.9 & 82.1 & 75.1 \\
\hline 17 & 12.04 & 11.12 & 15.0 & 6.5 & 6.50 & 11.0 & 80.2 & 81.9 & 76 \\
\hline 18 & 12.11 & 10.39 & 15.6 & 6.5 & 6.00 & 8.0 & 80.3 & 83.5 & 73 \\
\hline 19 & 10.59 & 9.45 & 14.4 & 4.5 & 7.00 & 10.0 & 82.8 & 81.1 & 76 \\
\hline S.Çanak-98 & 12.07 & 12.09 & 15.1 & 5.0 & 5.00 & 7.0 & 82.5 & 81.7 & 75.8 \\
\hline 21 & 12.31 & 12.41 & 15.9 & 7.0 & 5.00 & 10.0 & 79.6 & 81.2 & 71.1 \\
\hline 22 & 11.89 & 13.07 & 15.5 & 6.0 & 7.00 & 12.5 & 82.3 & 79.9 & 72.1 \\
\hline 23 & 11.54 & 12.30 & 15.6 & 6.0 & 6.50 & 10.5 & 79.9 & 80.8 & 73.6 \\
\hline 24 & 11.43 & 11.32 & 15.2 & 8.0 & 7.50 & 12.0 & 80.4 & 79.6 & 73.2 \\
\hline Svevo & 12.95 & 12.75 & 14.7 & 8.5 & 8.50 & 13.5 & 77.8 & 79.5 & 74.1 \\
\hline Ortalama & $11.66 \mathrm{~B}$ & $11.69 \mathrm{~B}$ & $15.2 \mathrm{~A}$ & $6.12 \mathrm{~B}$ & $6.26 \mathrm{~B}$ & $10.02 \mathrm{~A}$ & \multicolumn{3}{|c|}{81.53 A 80.39 A 72.59 B } \\
\hline DK\% & \multicolumn{3}{|c|}{4.47} & \multicolumn{3}{|c|}{12.74} & \multicolumn{3}{|c|}{2.24} \\
\hline
\end{tabular}

stres şartlarının hâkim olduğu Göllü lokasyonunda daha yüksek b değeri (24.9) elde edilmiştir. Bu sonuçlar yüksek sıcaklık stresinde sarı renk pigmentinin (b) artığını bildiren Taghouti ve ark. (2010); Rharrabtia ve ark. (2003); Tekdal ve Yıldırım (2015)'ın sonuçları ile de uyumludur. Gerek makarnalık ve gerekse bulgurluk kalitesi açısından son derece önemli görülen $b$ renk pigmentinin Güneydoğu Anadolu 1. alt bölgesinin uygun iklime sahip olması sanayici için dikkate değer bir faktördür.

\section{Tane verimi ve Performans Oranı}

Tane verimi (TV) bakımından lokasyonlar ve genotipler değerlendirildiğinde, kalite özelliklerinin aksine optimum şartlara sahip DYB-S ve DYB-K lokasyonlarının öne çıktığı görülmektedir (Çizelge 6). Yeterli yağışın alındığı (534 mm) Diyarbakır lokasyonunda sulama ile $\left(692.5 \mathrm{~kg} \mathrm{da}^{-1}\right)$ kuruya (638 $\mathrm{kg} \mathrm{da}^{-1}$ ) göre önemli bir artıșın sağlanamadığ görülmüştür. Uzun yıllar ortalamasının üzerindeki yağışa rağmen (Artuklu $600 \mathrm{~mm}$; K1zıltepe $403 \mathrm{~mm}$, Nusaybin $464 \mathrm{~mm}$ ) 1. alt bölgede yer alan MardinGöllü lokasyonunuda verim ortalaması $301 \mathrm{~kg} \mathrm{da}^{-1}$ ile \%53 lük bir azalıș söz konusu olmuștur. TV'ni düşüren en belirgin stres faktörünün dane doldurma dönemindeki yüksek sıcaklık olduğu Şekil 4, Şekil 5 ve Şekil 6'dan anlaşılabilmektedir. Benzer çalışmalarda yüksek sicaklığa maruz buğday genotiplerinde önemli düşme olduğunu bildiren Tekdal ve Yıldırım (2015), Kılıç ve Yağbasanlar (2003); Ansari ve ark. (2013) ile de uyumludur. Genotiplerin performansı bakımından, DYB-S lokasyonunda en yüksek TV $787.1 \mathrm{~kg} \mathrm{da}^{-1}$ ile G16'dan sağlanırken, en düşük TV de $584.8 \mathrm{~kg} \mathrm{da}^{-1}$ ile Aydın-93 çeşidinden elde edilmiştir. Aydın-93 çeşidi uzun boylu olup $\% 40$ oranında yatma 
Çizelge 6. Denemelerin yürütüldüğü lokasyonlara ait tane sarı renk değeri ile tane verimine ait ortalama değerler

\begin{tabular}{|c|c|c|c|c|c|c|}
\hline \multirow[t]{2}{*}{ Genotip } & \multicolumn{2}{|c|}{ Tane sarı renk içeriği (b) } & \multicolumn{3}{|c|}{ Tane Verimi $\left(\mathrm{kg} \mathrm{da}^{-1}\right)$} & \multirow[b]{2}{*}{$\operatorname{PERO}(\%)$} \\
\hline & DYB-K & $\begin{array}{l}\text { GÖLLÜ-K } \\
\text { (Mardin) }\end{array}$ & $\overline{\text { DYB-S }}$ & DYB-K & $\begin{array}{l}\text { Göllü-K } \\
\text { (Mardin) }\end{array}$ & \\
\hline 1 & 24.78 & 23.21 & 715.4 a-d & $620.2 \mathrm{abc}$ & $295.4 \mathrm{a}-\mathrm{e}$ & $48,0 \mathrm{a}-\mathrm{d}$ \\
\hline 2 & 21.88 & 24.10 & 660.6 a-d & $614.8 \mathrm{abc}$ & $248.3 \mathrm{~b}-\mathrm{f}$ & 39,9 a-d \\
\hline 3 & 23.60 & 25.99 & $627.5 \mathrm{~cd}$ & $587.9 \mathrm{bc}$ & $237.9 \mathrm{c}-\mathrm{f}$ & $40,8 \mathrm{a}-\mathrm{d}$ \\
\hline 4 & 24.79 & 25.87 & $731.5 \mathrm{abc}$ & $683.3 \mathrm{abc}$ & $359.0 \mathrm{ab}$ & $52,6 \mathrm{abc}$ \\
\hline Aydin-93 & 25.53 & 25.69 & $584.8 \mathrm{~d}$ & $590.6 \mathrm{bc}$ & $334.6 \mathrm{abc}$ & $57,3 \mathrm{a}$ \\
\hline 6 & 22.67 & 23.22 & 685.8 a-d & $595.0 \mathrm{bc}$ & 304.6 a-e & $51,4 \mathrm{abc}$ \\
\hline 7 & 20.58 & 20.19 & $774.0 \mathrm{ab}$ & 750.0 a & $363.5 \mathrm{ab}$ & 48,7 a-d \\
\hline 8 & 21.21 & 22.88 & 720.8 a-d & $658.8 \mathrm{abc}$ & $278.1 \mathrm{a}-\mathrm{f}$ & $42,5 \mathrm{a}-\mathrm{d}$ \\
\hline 9 & 27.32 & 27.88 & 708.1 a-d & $653.3 \mathrm{abc}$ & $280.2 \mathrm{a}-\mathrm{f}$ & 42,7 a-d \\
\hline Firat-93 & 22.84 & 23.21 & 721.5 a-d & $626.9 \mathrm{abc}$ & $356.5 \mathrm{abc}$ & $56,8 \mathrm{a}$ \\
\hline 11 & 24.80 & 25.10 & $\underline{696.5}$ a-d & $576.8 \mathrm{bc}$ & 194.0 e-f & $33,8 \mathrm{bcd}$ \\
\hline 12 & 21.92 & 23.66 & $634.0 \mathrm{~cd}$ & $590.6 \mathrm{bc}$ & $174.2 \mathbf{f}$ & $30,1 \mathrm{~d}$ \\
\hline 13 & 23.28 & 24.01 & 710.4 a-d & $644.9 \mathrm{abc}$ & 209.2 d-f & $32,7 \mathrm{~cd}$ \\
\hline 14 & 24.75 & 27.05 & $743.8 \mathrm{abc}$ & $710.2 \mathrm{ab}$ & 365.0 a & $51,5 \mathrm{abc}$ \\
\hline Fuatbey & 22.50 & 23.80 & 707.1 a-d & $641.0 \mathrm{abc}$ & $346.7 \mathrm{abc}$ & $54,1 \mathrm{abc}$ \\
\hline 16 & 23.09 & 25.47 & 787.1 a & $680.2 \mathrm{abc}$ & $344.6 \mathrm{abc}$ & 50,6 a-d \\
\hline 17 & 24.63 & 25.64 & 655.8 a-d & $643.8 \mathrm{abc}$ & $337.7 \mathrm{abc}$ & $52,9 \mathrm{abc}$ \\
\hline 18 & 24.13 & 25.58 & 683.3 a-d & $700.2 \mathrm{abc}$ & $292.5 \mathrm{a}-\mathrm{e}$ & $41,8 \mathrm{a}-\mathrm{d}$ \\
\hline 19 & 23.84 & 24.45 & $735.4 \mathrm{abc}$ & $677.9 \mathrm{abc}$ & $368.3 \mathrm{a}$ & $54,5 \mathrm{abc}$ \\
\hline S.Çanak-98 & 24.15 & 26.51 & 699.2 a-d & $663.0 \mathrm{abc}$ & $347.1 \mathrm{abc}$ & $52,7 \mathrm{abc}$ \\
\hline 21 & 20.72 & 24.50 & $652.1 \mathrm{a}-\mathrm{d}$ & 565.2 c & $262.5 \mathrm{a}-\mathrm{f}$ & $47,1 \mathrm{a}-\mathrm{d}$ \\
\hline 22 & 23.78 & 25.02 & $644.2 \mathrm{bcd}$ & $619.6 \mathrm{abc}$ & $284.0 \mathrm{a}-\mathrm{d}$ & 46,3 a-d \\
\hline 23 & 23.53 & 26.63 & 651.9 a-d & $628.1 \mathrm{abc}$ & $314.4 \mathrm{a}-\mathrm{d}$ & $50,2 \mathrm{a}-\mathrm{d}$ \\
\hline 24 & 25.28 & 25.41 & $730.8 \mathrm{abc}$ & $605.6 \mathrm{bc}$ & 294.8 a-e & 49,0 a-d \\
\hline Svevo & 26.96 & 27.45 & 650.4 a-d & $622.9 \mathrm{abc}$ & $345.4 \mathrm{abc}$ & $56,0 \mathrm{a}$ \\
\hline Ortalama & 23.70 B & $24.90 \mathrm{~A}$ & $692,5 \mathrm{~A}$ & 638,0 B & $301 \mathrm{C}$ & 47.34 \\
\hline V.K (\%) & 2.81 & & 7,36 & 8,0 & 14.2 & 16.7 \\
\hline
\end{tabular}

*: Aynı harf grubuna giren değerler Tukey \%5 önem seviyesine göre farklı değildir.

kaydedilmiştir. DYB-K lokasyonunda ise en yüksek TV $750 \mathrm{~kg} \mathrm{da}^{-1}$ ile G7'den, en düşük tane verimi de $565 \mathrm{~kg} \mathrm{da}^{-1}$ ile G21'den elde edilmiştir. Sicaklık stersinin yaşandiğ 1 Göllü lokasyonunda ise en yüksek TV 365.0 ve $368.3 \mathrm{~kg} \mathrm{da}^{-1}$ ile erkenci özelliklere sahip G14 ve G19 genotiplerinden, en düşük tane verimi de $174.2 \mathrm{~kg} \mathrm{da}^{-1}$ ile geççi bir özelliğe sahip G12 den elde edilmiştir. G14- ve G19'un ve Performans Oran1 (PERO) bakımından da (\%51.5 ve \%54.5) yüksek oranlara sahip oldukları görülmektedir (Çizelge 6). En düşük PERO'nun (\% 30.1) geççi bir özelliğe sahip G12'de kaydedilmesi şaşırtıcı olmamıştır. Bununla beraber sıcaklık stresine dayanmada erkencilik tek başına bir kriter olmayıp ancak yükssek sıcaklıktan kaçış olarak değerlendirilebilecek bir özellik olduğu anlaşılmaktadır. Genotip ortalamaları üzerinden verimde yarıya yakın meydana gelen bu azalma dane doldurma devresindeki yüksek sicaklığın sebep olduğu dane boyutundaki azalma (buruşuk dane/şevibi) ile ilgilidir. (Wardlaw ve ark. 1989b). Nitekim en yüksek TV'nin alındığı G19'daki BTA'daki azalma \%14 iken en düşük TV'nin alındığ 1 G12 deki azalma ise \%36 olmuştur. Biplot analizinde de TV ve BTA'nın aynı mega grupta yer alması bu hükmümüzü teyit etmektedir. Genotipler arasinda meydana gelen farkliliklar ise genotip $\mathrm{x}$ çevre interaksiyonunun etkisinden kaynaklandığ düşünülmekte olup, Şekil 4, Şekil 5 ve Şekil 6'daki meteorolojik verilerden de anlaşılmaktadır. 
Erkencilik ve tane boyutundaki değişim, sıcaklık stresinin yaşandığ 1 bu tür bölgelerde önemli bir seleksiyon kriteri olarak ele alınmalıdır. Nitekim normal şartlar olarak kabul ettiğimiz Diyarbakır lokasyonuna yakın değerde ve uzun yıllar ortalamasının üstünde yağış alan Göllü lokasyonundaki verimi sınırlayan en önemli faktörün yüksek sicaklık olduğu, PERO'yu belirlemede yeni bir yaklaşım olarak görülebilecek bu çalışmada çeşitlerin toleranslık durumlarını Tekdal ve Yıldırım (2017) sicaklığa hassasiyet indeksi ile izah etmeye çalışmışlardır. Araştırıcılar Firat-93'ün tolerant, Fuatbey-98 ve Sarıçanak-98'in ise orta tolerant olduklarını bildirmekle çalışmamızda söz konusu çeşitler için bulduğumuz yüksek PERO oranıyla (\%56.8, \%54.1, \%52.7) uyumlu Svevo için belirledikleri hassasiyet durumu ise çalışmamızda Svevo için bulduğumuz yüksek PERO (\%56) oranı ile uyumsuz bulunmuştur.

\section{Yüksek sıcaklığın dane doldurma dönemindeki etkileri}

Tane doldurma başlangıc1 10 Mayıs 16 Haziran tarihleri arasina denk gelen 2. Alt bölgedeki Diyarbakır lokasyonunda 1. Alt bölgeye göre gün içi yüksek sıcaklıkları nispeten daha düşük olduğu gözlemlenmiştir. Mayıs 22, 23 ve 24. günlerinde 30 ${ }^{\circ} \mathrm{C}$ üstü seyreden sicaklıkları müteakip Haziran ilk iki haftasına kadar $30{ }^{\circ} \mathrm{C}$ civarı seyretmiştir (Şekil 5 ve Şekil 6). Dane doldurma devresi boyunca sıcaklıklar kısa süreli de olsa $35{ }^{\circ} \mathrm{C}$ yi geçmemiştir. Buna göre Göllü lokasyonunun yer aldığı 1. Alt bölgede buğday yetiştiriciliğinin yüksek sıcaklık yönünden daha fazla maruz kaldığı ve stres şartlarının daha şiddetli olduğu anlamına gelmektedir. Buğday bitkisinde maksimum büyüme sicaklık değeri $42{ }^{\circ} \mathrm{C}$ olarak kabul edilmekle birlikte (Al-Khatiba ve Paulsen, 1999) $40{ }^{\circ} \mathrm{C}$ sicaklığın fotosentez oranını büyük oranda düşürdüğünden, bitkiler olum devresine girmek zorunda kalmaktadırlar. Nitekim artan sicaklık dereceleri bitki gelişiminin farklı proseslerini inhibe etmektedir (Ishak ve Mohammed, 1996). Bitki için tespit edilen sınır değerlerin üzerindeki sıcaklıklar fotosentez, membran bütünlüğü ve enzim stabilitesini içeren birçok fizyolojik faaliyette değişikliklere sebep olmaktadır (Nguyen ve Joshi, 1992.). Kök, sap, yaprak ve diğer organlarda biriken besin elementlerinin tümü daneye taşınmadan dane fizyolojik oluma geçmektedir. Neticede dane buruşuk ve zayıf kalmaktadır. Tolerans derecelerini belirlemek üzere buğday bitkisinde yapılan bir çalışmada sicaklığın $32{ }^{\circ} \mathrm{C}$ den $42{ }^{\circ} \mathrm{C}$ ye yükseltmesiyle fotosentetik aktivitedeki protoplast, kloroplast ve thylakos (pigment içeren keseler) seviyelerinde keskin bir düşüş gözlendiği, en yüksek fotosentetik oranın ise $22{ }^{\circ} \mathrm{C}$ de belirlendiği bildirilmiştir (Al-Khatiba ve Paulsen, 1999).

\section{Biplot analizleri}

Özellikler arası ilişkileri görsel inceleme ve değerlendirmeye esas lokasyon, genotip ve verileri ile oluşturulan Biplot grafikleri Şekil 9, Şekil 10 ve Şekil 11'de verilmiştir. Genotip özellik ilişkisini gösteren Biplot grafiği (Şekil 9) incelendiğinde toplam varyason \% 58.29 olarak belirlenirken, bu varyasyonun \% 36.75'i birinci ana bileşen (PC1) ve $\%$ 21.54'ü ise ikinci ana bileşen (PC2) tarafindan temsil edildiği görülmektedir. Elde edilen biplot grafiğine göre G18 ve G4 grafik orjine yakın yerde (ortada) oldukları için, incelenen tüm özellikler bakımından ortalamanın üstünde, dolayısıyla tüm özellikler bakımından kabul gören (appricate) genotipler olarak değerlendirilebilir. BS değeri bakımından G12, PO ve BB değeri için Aydın-93 ve G3, mSDS ve b değerleri için Svevo ve G9 en yüksek değerlere sahip genotipler/çeşitler olarak belirlenmiştir. HL için G14, G16, TV için G7, G16, G14 ve Sarıçanak-98 genotipleri/çeşitleri en yüksek değerlere sahip olmuşlardır. Şekil 9 incelendiğinde 5 adet mega-grup'un oluştuğu görülmektedir. Buna göre aynı Mega-Grup içerisinde genotipler ilgili özellikler için yüksek değerlere sahip olarak yorumlanabilir. Örneğin aynı mega-grupta yer alan Svevo, G9 ve G17 mSDS ve b değerleri bakımından en yüksek değerlere sahip olmuştur. Grafiği oluşturan değerler Çizelge 5 ve Çizelge 6'da verilmiştir. Lokasyon-özellik ilişkisini gösteren biplot grafiğinde (Şekil 10) 3 mega grup meydana gelmiş olup, $b$, mSDS ve PO bakımından en yüksek değerler Göllü (Mardin) lokasyonundan, BB için en yüksek değerler DYB-K lokasyonundan, BS, HL, TV, BTA için ise en yüksek değerler DYB-S lokasyonundan elde edilmiştir. Bilhassa PO, mSDS ve $b$ için en yüksek değerlerin Göllü(Mardin) lokasyonundan elde edilmiş olması, kaliteli durum buğdayı yetiştiriciliği açısından bu lokasyonun spesifik bir yere sahip olduğu sonucuna varılabilir. 


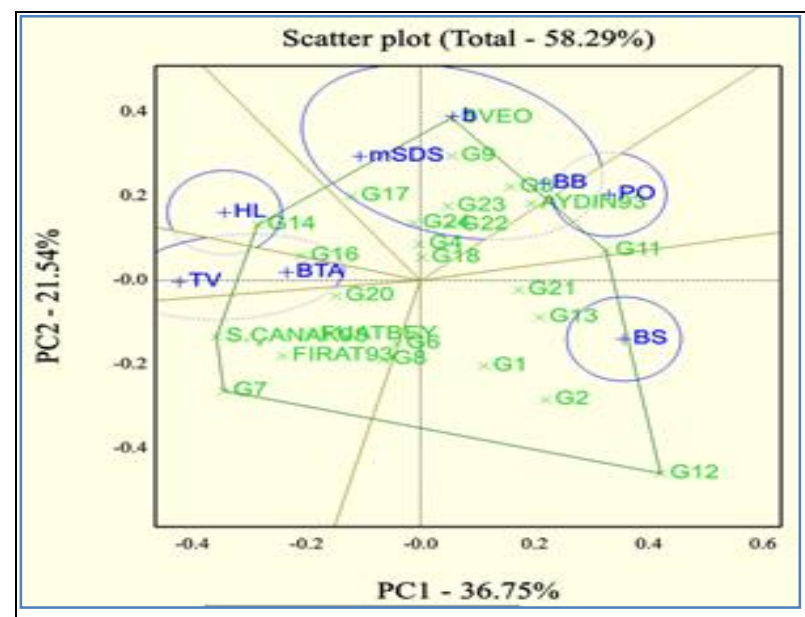

Şekil 9. Genotip - Özellik İlişkisini Gösteren biplot grafiğgi

Tane verimi bakımından genotiplerin stabilitesini gösteren ranking biplot grafiği değerlendirildiğinde (Şekil 11), toplam varyasyon \% 91.03 olurken, bu varyasyonun \% 70.42'si birinci ana bileşen, \% 20.6's1 ise ikinci ana bileşen tarafindan temsil edilmiştir. Biplot metodolojisine göre grafiği dikine ortadan kesen çizginin sağında yer alan genotipler ortalamadan yüksek olduğu kabul edilmektedir. Grafiği yatay olarak ayıran çizginin en yakınında yer alan genotipler ise incelenen özellik bakımından en stabil genotipler olarak tanımlanırlar. Buna göre, G7 en yüksek verime sahip olmasına rağmen, grafiği yatay kesen çizginin biraz

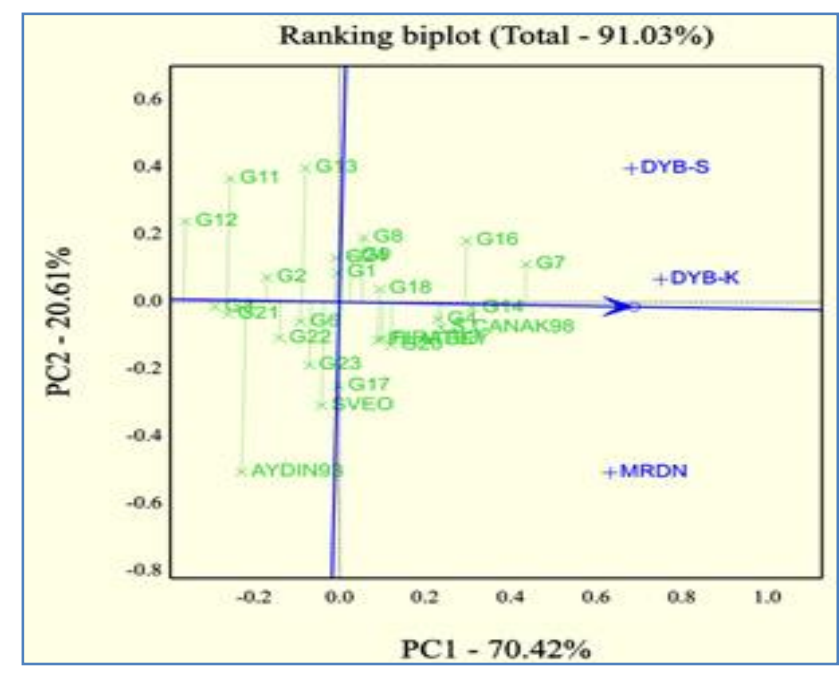

Şekil 11. Tane verimi bakımından genotiplerin stabilitesini gösteren ranking biplot grafiği

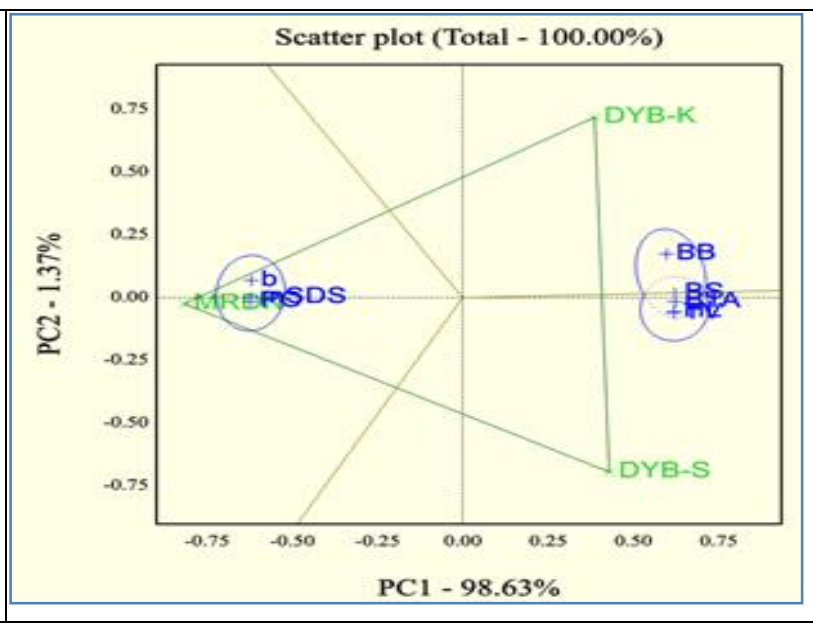

Şekil 10. Lokasyon- özellik ilişkisini gösteren biplot grafiği.

uzağında yer almasından stabilite seviyesi orta, yatay çizgiden daha uzakta yer alan G16 genotipinin ise daha az stabil olduğu da anlaşılmaktadır. G14 genotipi ise yatay çizgiye en yakın ve dikey grafiği uzak olması ile hem stabil hem de stabilite değeri en yüksek genotip olarak kabul edilmektedir. G16 ve G7 ise verim seviyeleri yüksek ama daha çok spesifik bölgelere uygun genotipler olarak tanımlanabilir.

\section{SONUÇ}

Güneydoğu Anadolu Bölgesi güney kesiminde dane doldurma devresinde cereyan eden yüksek sicaklıklar, buğdayın verimini sınırlayan önemli stres faktörlerinin başında gelmektedir. En az kuraklık kadar önem verilmesi gereken bir stres faktörü $\left(>35{ }^{\circ} \mathrm{C}\right)$ olan yüksek sicaklığın yeterli yağışa rağmen genotip ortalamaları üzerinden tane veriminin \%50'lere kadar düşmesine sebep olmas1 ihmal edilebilecek bir faktör olmadığını göstermektedir. Yüksek sıcaklık şartlarında düşük verime rağmen $\mathrm{PO}, \mathrm{mSDS}$ ve $\mathrm{b}$ tane renk pigmenti yönünden arzu edilen seviyelerin üstünde değerler elde edilirken, normal şartların yaşandığı Diyarbakır lokasyonunda ise yüksek tane verimi ile birlikte makul kalite seviyelerine de ulaşılmıștır. Tane verimindeki azalmaya etkili esas faktörün, dane dolum periyodunun kısalmasına bağlı dane ebadındaki küçülme (buruşuk) olduğu anlaşılmıştır. $\mathrm{Bu}$ itibarla çeşit geliştirme programlarında yüksek sicaklık stresini azaltmaya esas; erkenci, bitki örtü sıcaklığı düşük, yeşil kalma (Tekdal ve Yıldırım, 2017) 
ve dane doldurma süreleri uzun (Kılıç, 2003), tane ebadını muhafaza edebilen ve depo edilen besinlerin taneye aktarılmasında yüksek performans gösteren genotiplerin seçilmesi isabetli olacaktır. Ayrıca yüksek sıcaklık stresine etki eden moleküler kontrol mekanizmalarının tespiti edilmesi, fonksiyonel genomik analizler aracılığıyla geleneksel ve moleküler 1slah yöntemlerinin biyoteknolojik esasta entegre edilerek tolerant çeşitlerin 1slah edilmesi (Yıldız ve Terzi, 2007) ve yetiştirme tekniklerinin geliştirilmesi gibi stratejiler de araştırma konuları olmaya değerdir.

\section{KAYNAKLAR}

Aktaş, H., Karaman, M., Erdemci, I., Kendal, E., Tekdal, S., Kılıç, H., Oral, E., 2017. sentetik ve modern ekmeklik buğday genotiplerinin (triticum aestivum 1.) verim ve kalite özelliklerinin karşılaştırılması Uluslararası Tarım ve Yaban Hayatı Bilimleri Dergisi, 3(1):25 - 32

Anonim, 2001. tarımsal değerleri ölçme denemeleri teknik talimatı. Tarım ve Köy işleri Bakanlığı, Koruma Kontrol Genel Müdürlüğü, Tohumluk Tescil ve Sertifikasyon Merkezi Müdürlügü. s35

Anonim, 2008. Tarım, g1da ve hayvancılık bakanlığ kayıtları Mardin.

Anonim, 2011. Buğdayla ilgili genel bilgiler. Tarım Bakanlığı.

Ansari, W.M., Rao. Y.R, Verma, R.S., Shukla, A., Tuteja, N., 2013. Comparative physiological response of wheat genotypes under terminal heat stress. Plant Signaling and Behavior, 8:1-6.

Atlı, A., 2007. Bölgede üretilen buğday çeşitlerinin kalitesi ve sanayiye uygunluğu. Tarım ve Köyişleri Bakanlı̆̆ Tohumculuk Çallştayl, 06-07 Mart Şanliurfa.

Aydoğan, S., Göçmen, A., Şahin, Ş., Demir, B., Önmez, H., Türköz, M., Çeri, S., 2012. Bazı makarnalık buğday çeşitlerinin kalite özelliklerinin belirlenmesi. Tarla Bitkileri Merkez Araştırma Enstitüsü Dergisi, 21(1):1-7.

Barutçular, C., Yildirim, M., Koc, M., Dizlek, H., Akinci, C., EL Sabagh, A., Saneoka, H., Ueda, A., Islam, M., Toptas, İ., Albayrak, Ö., Tanrikulu, A., 2016. Quality traits performance of bread wheat genotypes under drought and heat stress conditions. Fresenius Environmental Bulletin, 25(12a):61596165

Bayer, T., 2019. Mardin ve Nusaybin'de uzun yıllık yağış ve sicaklık gidişlerinin kuraklık açısından değerlendirilmesi İlk Çağlardan Modern Döneme Tarihten İzler II. Editörler Prof. Dr. M. Doğan Karacoşkun Prof. Dr. Osman Köse Berikan Yayınevi, s. 298-320.
Bilgin, O., Korkut, K.Z., 2005. Bazı ekmeklik buğday çeşit ve hatlarının tane verimi ve bazı fenolojik özelliklerinin belirlenmesi. Tekirda $\breve{g}$ Ziraat Fakültesi Dergisi, 2:57-65

Blum, A., 1988. Plant breeding for stres environments. CRC Press. Boca Raton. FL., pp: 223

Blumenthal, C.S., Bekes, F., Batey, I.L., Wrigley, C.W., Moss, H.J., Mares, D.J., Barlow, E.W.R., 1991. Interpretation of grain quality results from wheat variety trials with reference to high temperature stress. Australian Journal of Agricultural Research, 42:325-334.

Borghi, B, Corbellini, M, Minoia, C, Palumbo, M, di Fonzo, N, Perenzin, M., 1997. Effects of mediterranean climate on wheat bread-making quality. European Journal of Agronomy, 6:145-154.

Castro, M., Peterson, C., J., Dalla Rizza, M., Díaz Dellavalle, P., Vázquez, D., Ibáñez, V., Ross, A., 2007. Influence of heat stress on wheat grain characteristics and protein molecular weight distribution. In: Buck, H. T. ve ark. (eds.), Wheat production in stressed environments. Developments in plant breeding, 12:365-371.

Dias, A.S., Bagulho, A.S., Lidon, F.C., 2008. Ultrastructure and biochemical traits of bread and durum wheat grains under heat stress. Brazilian Journal of Plant Physiology, 20:323-333.

Dupont, F.M., Altenbach, S.B., 2003. Molecular and biochemical impacts of environmental factors on wheat grain development and protein synthesis. Journal of Cereal Science, 38:133-146.

Elbashir, A.A., Gorafi, Y.S.A., Tahir, I.S.A., Kim, J.S., Tsujimoto, H., 2017. Wheat multiple synthetic derivatives: a new source for heat stress tolerance adaptive traits. Breeding Scence, 67(3):248-256.

Elgün, A., 2017. Buğday genomu ve kalitesine endüstriyel yaklaşım http://www.millermagazine.com/bugday-genomuve-kalitesine-endustriyel-yaklasim/.html

Erekul, O., Yiğit, A., 2018. Buğdayda tane dolum dönemindeki yüksek sıcaklığın protein yapısına etkisi. Uluslararası Tarım Çevre ve Sağlık Kongresi, Aydin, 26-28 Ekim.

FAO, 2013. Birleşmiş milletler gıda ve tarım örgütü istatistikleri. http://www.fao.org/nr/water/aquastat/d ata/query/data/query/html.

Farooq, M., Bramley, H., Palta, J.A., Siddique, H.M., 2011. Heat stress in wheat during reproductive and grain-filling phases. Critical Reviews in Plant Sciences, 30(1):1-17.

Firat, A.E., 1978. Inheritance and association of earliness and grain yield in four winter $\mathrm{x}$ spring wheat crosses (Triticum aestivum L. em Thell), Master Thesis, Oregon State University, Oregon, OR. 
Graybosh, R.A., Peterson, C.J., Baenziger, P.S., Shelton, D.R., 1995. Environmental modification of hard red winter wheat flour protein composition. Journal of Cereal Science, 22:45-51

İlker, E., Tonk, F.A., Çaylak, Ö., Tosun, M., Özmen, I., 2009. Assessment of genotype $\mathrm{x}$ environment interactions for grain yield in maize hybrids using AMMI and GGE biplot analyses. Turkish Journal of Field Crops, 14(2):123-135.

Kanbertay, M., 1987. Dört makarnalık buğday melezinde dönme ve diğer bazı tarımsal özelliklerin kalıtımı üzerinde araştırmalar, Ege Bölge Zirai Araştırma Enstitüsü Doktora Çalışma Özetleri, Yayın no: 75, İzmir, 248-276.

Karaduman, Y., Ercan, R., 2011. Bisküvilik için seçilmiş ileri kademe yumuşak ekmeklik buğday hatlarının kuru ve sulu koşullarda verim ve bazı tane özellikleri. Tarla Bitkileri Merkez Araştırma Enstitüsü Dergisi, 20(2):1-9.

Kendal, E., Sayar, M.S., 2016. The stability of some spring triticale genotypes using biplot analysis. The Journal of Animal ve Plant Sciences, 26(3):754765.

Kılıç, H., 2003. Güneydoğu Anadolu Bölgesi koşullarında makarnalık buğday (Triticum turgidum ssp durum) ceşitlerinin bazı tarımsal ve kalite özellikleri ile stabilitesi üzerine araştırmalar. Doktora Tezi. Çukurova Üniversitesi. Fen Bilimleri Enstitüsü. Adana.

Kılıç, H., Yağbasanlar, T., 2003. Güneydoğu Anadolu Bölgesi koşullarında makarnalık buğday (Triticum turgidum ssp durum) çeşitlerinin bazı kalite özelliklerinin genotip $\mathrm{x}$ çevre interaksiyonları üzerinde araştırmalar. Türkiye 5. Tarla Bitkileri Kongresi, 13-17 Ekim, 2003, Diyarbakır.

Kılıç, H., Tekdal, S., Kendal, E., Aktaş, H., 2012. Augmented deneme desenine dayalı ileri kademe makarnalık buğday (Triticum turgidum ssp durum) Hatlarının biplot analiz yöntemi ile değerlendirilmesi. KSU Doğa Bilimleri, Dergisi, 15(4):18-25.

Kılıç, H., Türk, Z., 2016. Farklı toprak ișleme tekniklerinin mercimekte (Lens culinaris medik.) verim ve baz1 verim unsurları ile yabanc1 ot kesafetine etkisi. Trakya University Journal of Natural Sciences, 17(1):55-63,

Kızılgeçi, F., Albayrak, Ö., Yıldırım, M., 2019. Evaluation of thirteen durum wheat (Triticum durum desf.) genotypes suitable for multiple environments using GGE biplot analysis. Fresenius Environmental Bulletin, 28(9):6873-6882.

Mcdonald, G.K., Sutton, B.G., Ellıson, F.W., 1983. The effect of time of sowing on the grain yield of irrigated wheat in the Namoi Valley, New South
Wales. Australian Journal of Agricultural Research, 34:229-240

MGM, 2020. Ortalama sicaklık verisinin Mayıs ay1 istatistiksel analizi. Türkiye Mayıs ayı ortalama sıcaklık verisinin 1979-2016 yılları arasında dağılımı T.C Orman Ve Su İşleri Bakanlığı Meteoroloji Genel Müdürlügü. https://www.mgm.gov .tr/FILES/resmi-istatistikler/T urkiye-OrtalamaSicaklik.pdf ve https://www.mgm.gov.tr/FILES /resmiistatistikler/parametreAnalizi/TurkiyeMaximu m-Sicaklik-Ortalamasi.pdf, 26.03.02020,

MÜSAD, 2019. Makarna üreticileri ve sanayicileri derneği sektör raporu Ocak-Temmuz 2019: http://musad.org/wpcontent/uploads/2019/09/Makar na-Sekt\%C3\%B6rR aporu-7-Ayl\%C4\%B1k.pdf, 18.03.2019.

Mut, Z., Albayrak, S., Töngel, Ö., 2006. Tritikale (Triticosecale Wittmack) hatlarının tane verimi ve bazı özelliklerinin belirlenmesi. Ankara Üniversitesi Ziraat Fakültesi, Tarım Bilimleri Dergisi, 12(1):5664.

Nguyen., H.T., Joshi, P.C., 1992. Molecular Strategies for the genetic dissection of water and high temperature stress adaptation in cereal crops, Proceedings of an International Symposium on the Adaptation of Food Crops to Temperature and Water Stress, Taiwan, 119: 13-18 August.

Peterson, C.J., Graybosch, R.A., Boenziger, P.S., Grambacher, A.W., 1992. Genotype and Environment Effects on Quality Characteristics of Hard Red Winter Wheat. Crop Science, 32:98-103.

Rawson, H.M., 1986. High-temperature-tolerant wheat: a description of variation and a search for some limitations to productivity. Field Crops Research, 14:197-212.

Rharrabti, Y., Villegas, D., Royo, C., Martos-Nunez, V., García del Moral, L.F., 2003. Durum wheat quality in Mediterranean environments II. Influence of climatic variables and relationships between quality parameters. Field Crops Research, 80:133140.

Sakin, M.A., Yıldırım, A., Gökmen, S., 2004. Tokat Kazova Koşullarında Bazı Makarnalık Buğday Genotiplerinin Verim, Verim Unsurları ile Kalite Özelliklerinin Belirlenmesi. A.Ü. Ziraat Fakültesi Tarım Bilimleri Dergisi, 10(4):481-489.

Sakin, M.A., Naneli, İ., Göy. A.G., Özdemir, K., 2015. Bazı ekmeklik buğday (Triticum aestivum L.) çeşitlerinin Tokat-Zile Koșullarında verim ve verim komponentlerinin belirlenmesi. Gaziosmanpaşa Üniversitesi Ziraat Fakültesi Dergisi, 32(3):119132.

SAS Institute 2002. JMP Design of Experiments, Version 5 Copyright (C) 2002 by SAS Institute Inc., Cary, NC, USA.2002. 
Sharma, R.C., 1994. Early Generation Selection for Grain Filling Period in Wheat. Crop Breeding, 34:945-948.

Shah, N.H., Paulsen, G.M., 2003. Interaction of drought and high temperature on photosynthesis and grainfilling of wheat. Plant and Soil, 257:219-226.

Schapendonk, A.H.C.M., Xu, H.Y, Van Der Putten, P.E.L., Spiertz, J.H.J., 2007. Heat-shock effects on photosynthesis and sink-source dynamics in wheat (Triticum aestivum L.). Wageningen Journal of Life Sciences, 55(I):37-54.

Sial, M.A., Arain, M.A., Khanzada, S., Naqvi, M.H., Dahot, M.U., Nizamani, N., 2005. Yield and quality parameters of wheat genotypes as affected by sowing dates and high temperature stress. Pakistan Journal of Botany, 37(3):575-584

Şen, Ö.L., Bozkurt, D., Göktürk, O.M., Dündar, B., Altürk, B., 2017. Türkiye'de iklim değişikliği ve olası etkileri. Conference: 3. Taşkın Sempozyumu.

Taghouti, M., Gaboun, F., Nsarellah, N., Rhrib, R., ElHaila, M., Kamar, M., Abbad Andaloussi, F.S., Udupa, M., 2010. Genotype x Environment interaction for quality traits in durum wheat cultivars adapted to different environments. African Journal of Biotechnology, 9(21):3054-3062.

Tekdal, S., Kendal, E., Aktaş, H., Karaman, M., Doğan, H., Kılıç, H., Karahan, H., 2014. Güneydoğu Anadolu Bölgesi'nde yabanc1 orijinli bazı durum buğday genotiplerinin adaptasyon kabiliyetlerinin belirlenmesi. Trakya University Journal of Natural Sciences, 15(1): 47-52.

Tekdal, S., Yıldırım, M., 2015. Sicaklık stresine maruz bırakılan bazı makarnalık buğday çeșitlerinin kalite özelliklerinin incelenmesi. Dicle Üniversitesi Fen Bilimleri Dergisi, 4(2): 68-76.

Tekdal, S., Yıldırım, M., 2017. Bazı makarnalık buğday genotiplerinde fizyolojik ve morfolojik parametrelerin sıcaklık stresi ile ilişkisi. Türk. Doğa ve Fen Dergisi, 6(2):575-584.

TMO, 2018. Hububat alım fiyat ve politikaları http://www.tmo.gov.tr/Main.aspx?ID=9038

TMO, 2019. Toprak Mahsulleri Ofisi Genel Müdürlüğü 2018 Yılı Hububat Sektör Raporu. Ankara 2019 Erişim tarihi: 18.03.2020: http://www.tmo.gov.tr/U pload/Document/hububatsektorraporu2018.pdf.

URL, 1. 2019. https://www.nkfu.com/turkiyede-sicaklikdegisimi-ve-dagilimi/ Türkiye'de sıcaklık dağılımı ve değişimi, 23 Şubat 2020.

Wardlaw, I.F., Dawson, I.A., Munibi, P., Fewster, R., 1989a. The tolerance of wheat to high temperatures during reproductive growth. I. Survey procedures and general response patterns. Australian Journal of Agricultural Research, 40:1-13.

Wardlaw, I.F., Dawson, I.A. Munıbı, P., 1989b. The tolerance of wheat to high temperatures during reproductive growth. II. Grain development. Australian Journal of Agricultural Research, 40:1524

Wardlaw, I.F., Wrigley, C.W., 1994. Heat tolerance in temperate cereals: an overview. Australian Journal of Plant Physiology, 21:695-703.

Wiegand, C.L., Cuellar, J.A., 1981. Duration of grain filling and kernel weight of wheat as affected by temperature. Crop Science, 21:95-101.

Williams, P., El-Haremein, F.J., Nakkoul, B., Rihawi, S., 1988. Crop quality evaluation methods and guidelines. ICARDA. Technical manual, 14 (Rev.1).

Yan, W., 2001. GGE biplot: A windows application for graphical analysis of multienvironment trial data and other types of two way data. Agronomy Journal, 93: 1111-1118.

Yan, W., Kang, M.S., 2003. GGE Biplot Analysis: A graphical tool for breeders, geneticists, and agronomists. CRC Press, Boca Raton, FL, pp.288.

Yan, W., 2002. Singular value partitioning for biplot analysis of multi-environment trial data. Agronomy Journal, 94:990-996.

Yıldız, M., Terzi, H., 2007. Bitkilerin yüksek sıcaklık stresine toleransının hücre canlılığı ve fotosentetik pigmentasyon testleri ile belirlenmesi. Erciyes Üniversitesi Fen Bilimleri Enstitüsü Dergisi, 23:4760 .

Zahedi, M., Jenner, C.F., 2003. Analysis of effects in wheat of high temperature on grain filling attributes estimated from mathematical models of grain filling. Journal of Agricultural Science, 141:203-212.

Zhang, Y., Pan, J., Huang, X., Guo, D., Lou, H., Hou, Z., Su, M., Liang, R., Xie, C., You, M., Baoyun, L., 2017. Differential effects of a post-anthesis heat stress on wheat (Triticum aestivum L.) grain proteome determined by iTRAQ Scientific Reports 7:1-11. 